University of San Diego

Digital USD

\title{
Confronting the Intra-Racial Gender Gap: A Quantitative Study of the Impact of Gender on African American Students' Perceptions of Campus Climate at a Predominantly White Institution
}

Tiffany N. Carpenter EdD

University of San Diego

Follow this and additional works at: https://digital.sandiego.edu/dissertations

Part of the Leadership Studies Commons

\section{Digital USD Citation}

Carpenter, Tiffany N. EdD, "Confronting the Intra-Racial Gender Gap: A Quantitative Study of the Impact of Gender on African American Students' Perceptions of Campus Climate at a Predominantly White Institution" (2005). Dissertations. 755.

https://digital.sandiego.edu/dissertations/755

This Dissertation: Open Access is brought to you for free and open access by the Theses and Dissertations at Digital USD. It has been accepted for inclusion in Dissertations by an authorized administrator of Digital USD. For more information, please contact digital@sandiego.edu. 


\title{
CONFRONTING THE INTRA-RACIAL GENDER GAP: A QUANTITATIVE STUDY OF THE IMPACT OF GENDER ON AFRICAN AMERICAN STUDENTS' PERCEPTIONS OF CAMPUS CLIMATE AT A PREDOMINIATELY WHITE INSTITUTION
}

\author{
by \\ TIFFANY NICOLE CARPENTER \\ A dissertation submitted in partial fulfillment \\ of the requirements for the degree of \\ Doctor of Education \\ University of San Diego
}

May, 2005

Dissertation Committee

Fred J. Galloway, Ed.D

Robert Donmoyer, Ph.D

Cheryl Getz, Ed.D 
Copyright $(\mathcal{O}$ by Tiffany N. Carpenter All Rights Reserved 


\begin{abstract}
For the last decade, the attainment gap in college graduation rates between Black males and females has continued to grow, despite the best efforts of researchers interested in identifying both its causes and suggesting possible policy remedies. Although much of the work has focused on the search for cognitive differences between African American males and females, there has been little, if any, research on the different ways that Black males and females may perceive their campus climate. In an attempt to broaden the literature in this area, this study examined the perceptions of 366 undergraduate African American students at a predominately White institution regarding three specific dimensions of campus climate - the amount of institutional support received, the level of social integration, and the student's level of self-efficacy. After constructing a series of indices for each of the dimensions as well as an overall index for each respondent, multiple regression analysis was used to determine the extent to which gender and other demographic factors may have contributed to the students' perceptions of institutional support, social support, and self-efficacy.

The findings from the study revealed few differences in the ways that Black males and females perceived the campus climate at the institution under study; in fact, the only significant difference was in the area of social support where males felt more supported than females. However, the results of the regression analysis revealed that demographic factors played a significant role in explaining the student's overall perceptions of campus climate, as well as why some students felt more socially supported and self-efficacious than others. Specifically, age, gender, marital status, campus employment, membership in sororities, fraternities, and the Black Student Association were all significant predictors
\end{abstract}


of social support, while the student's collegiate grade point average was the only predictor for self-efficacy.

Recommendations for future research include examining the perceptions of intraracial groups at private four-year institutions as well as community colleges; testing for differences in campus climate between White institutions and Historically Black Colleges and Universities; and expanding upon the qualitative component of this dissertation to include a more nuanced discussion of individual students. 


\section{DEDICATION}

I would like to dedicate my dissertation to my parents, Frances and Hank Carpenter; to my siblings, Tracey and Tony Carpenter; and to my fiancé George Awkard. Words cannot fully express the thanks and gratitude I have for all of your support. It has been a very long and arduous journey, upon which numerous sacrifices and hardships have ensued, but despite the most difficult hurdles in the road, I never allowed the daunting experience to prevent me from achieving my goal. I never gave up; I kept pressing forward; and for this, I dedicate my dissertation to all of you.

I am eternally grateful to my parents for all the sacrifices they, too, had to endure throughout this journey. Thank you for the endless encouragement you gave to ensure I remained strong. I appreciate your patience, understanding, and strength that helped guide me through my final product. Thank you for providing me with a positive, nourishing, and secure childhood, and for instilling in me the value of education and the confidence to pursue and follow my dreams. I greatly benefited from the wisdom, direction, and love you shared with me throughout this journey.

I would also like to thank my fiancé. You have given me more encouragement and support than I could have ever asked for, you were there walking the campus with me through the laborious data collection, and throughout this time your love truly shined. I appreciate your understanding for the numerous evenings and weekends we spent apart while I worked on my dissertation. You always understood; you were always supportive; and your love and care was paramount. You are my rock and my foundation, and when I fall, your love and strength are there to help me stand tall through the toughest of times. For this I say, "Thank you and I love you." 
And, most importantly, I would like to give all my thanks to God. For without you none of this was possible. Your strength kept me; your wisdom directed me; and your faith saw me through. Thank you, God! 


\section{ACKOWLEDGMENTS}

There are several people who have supported me throughout my research and the preparation of this study. I would like to acknowledge my dissertation committee for their help and support throughout this long process, and for helping me bring my long-term commitment to fruition.

I would like to thank Dr. Fred Galloway, the chair of my dissertation committee, for always making himself available and for giving me direction and support in this endeavor. His incredible knowledge of quantitative statistics ignited my interest, and his ongoing encouragement and support helped me to confidently conduct quantitative research. I am appreciative of the inordinate amount of time he spent reviewing and editing my chapters; his thorough and timely feedback was invaluable. His knowledge, encouragement, and kindness will always be remembered.

I would like to also thank Dr. Robert Donmoyer for his direction and support in helping me solidify a research topic and crafting the beginning stages of my paper. His feedback was prescriptive and thought provoking. He helped me to make more conscious and careful decisions about my writing. His expertise in qualitative research methods and writing techniques will forever be valued.

I am also thankful to Dr. Cheryl Getz, the third member of my committee, for helping me with my literature review. I appreciate her personal interest in helping me to uncover various topics within the literature about African American students in higher education. Her support and advice about the arrangement of the chapter and about the specific areas of interest within this topic helped me craft a comprehensive literature 
review. I greatly appreciate her timely feedback and the many questions posed and suggestions provided. 
Financial Aid

Social Support and Integration................................................. 30

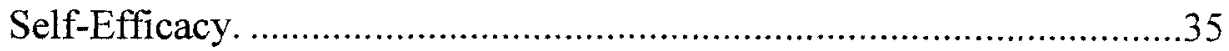

3. RESEARCH METHODOLOGY AND PROCEDURES ...........................40

Data Collection Method...................................................................40

Subjects and Sampling..........................................................

Phases and Time Period of the Study. ..............................................41

Validity and Reliability...........................................................42

Quantitative Research Design..............................................42

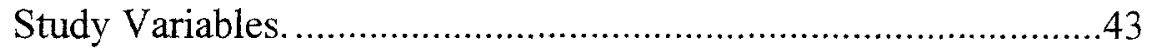

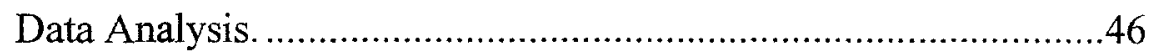

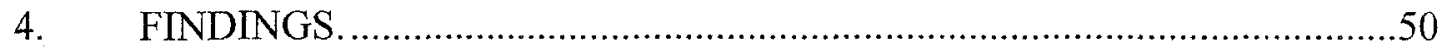

Sample and Survey Procedures...................................................50

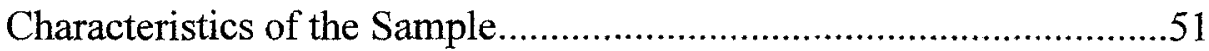

Effects of the Independent Variables on the Dependent Variables. .....58

Significant Demographic Variables...............................................59

Respondents' Qualitative Information on the Open-ended Question...72

Summary of Significant Findings. ............................................... 75

5. SUMMARY, CONCLUSIONS, DISCUSSION AND

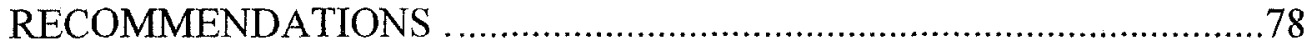

Discussion/Contribution to the Literature .........................................80

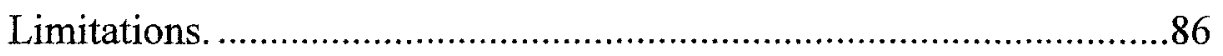

xii 
Recommendations for Future Research .......................................87

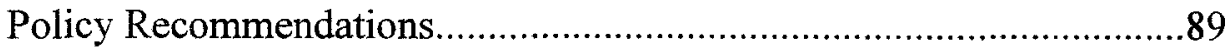

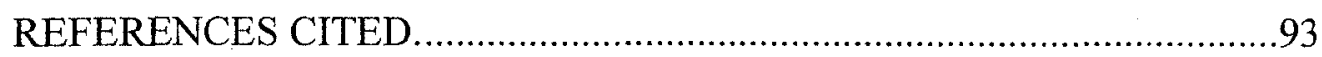

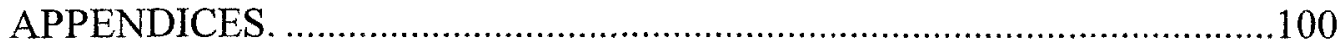

A- Letter of Introduction to the Undergraduates. ...............................100

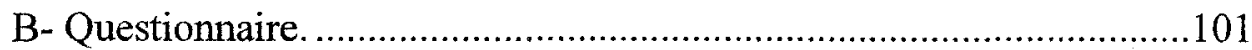

C-Answers to the Open-Ended Question on the Survey .....................104 


\section{LIST OF TABLES}

TABLE

1. Specification of Independent Variables. .44

2. Specification of Dependent Variables. .46

3. Demographic Characteristics of Sample. .53

4. Academic Characteristics of the Sample. .55

5. Sample Means and Standard Deviations of the Twelve Statements for Social Support Variable .

6. Sample Means and Standard Deviations for the Twelve Statements for Institutional Support Variable

7. Sample Means and Standard Deviations for the Twelve Statements for Self-Efficacy .58

8. Significant Independent Variables for Social Supports

9. Significant Independent Variables for the Dependent Variable, The Majority Of My High School Friends Are African American ....

10. Significant Independent Variables for the Dependent Variable,

The Majority Of My Peers At The University Are African American

11. Significant Independent Variables for the Dependent Variable, The Majority Of My High School Friends Attend This University

12. Significant Independent Variables for the Dependent Variable, I am Involved With The Student Union Here At This College.

13. Significant Independent Variables for the Dependent Variable, I am Involved With Intramural Sports

14. Significant Independent Variables for the Dependent Variable, I am Involved With Extracurricular Activities

xiv 
15. Significant Independent Variables for the Dependent Variable, I am Involved With Social Gatherings

16. Significant Independent Variables for Institutional Support. .66

17. Significant Independent Variables for the Dependent Variable, The Financial Aid Office Has Been Supportive In Meeting My Financial Needs

18. Significant Independent Variables for Self-Efficacy ...............................68

19. Significant Independent Variables for the Dependent Variable, I Feel Good About My Current GPA

20. Significant Independent Variables for the Dependent Variable, I Can Graduate From College In Four Years .

21. Independent Variables That Are Significant In All Three Areas of Campus Climate 


\section{Chapter One}

\section{BACKGROUND TO THE STUDY}

As you saunter across the campuses of predominately White institutions (PWI's) in America today, an interesting phenomenon is on display: the absence of Black males. In 1990, as a Black female attending a PWI, I was confronted with the startling reality of seeing fewer Black males on the college campus than Black females. I am a thirtysomething Black female who is currently working on a doctoral degree. Until recently, I felt fairly confident that my life partner would posses a similar educational background; however, with more and more Black males disappearing from the higher educational milieu, it is difficult to assume that my future life partner will have a college degree.

\section{African American College Statistics}

The alarming decline of Black males in higher education has become a pervasive problem in our society in the last two decades. As a result of this decline and disappearance, African American males have often been referred to as an "endangered species". The description, to some extent, applies metaphorically to not only the participation of Black males in higher education but to the current status of Black males in American society as a whole. This questionable disappearance of Black males seems to create a sense of ambiguity as to not only why the plight of Black males in higher education exists, but why it has continued over the last 20 years.

Statistics indicate that more Black students are attending college today than at any time in our nation's history (Slater, 1994). However, this increase is a result of Black females attending college in increasing numbers; Black males are enrolling in and graduating from institutions of higher education in fewer numbers than Black females 
(Slater, 1994). In fact, "the absence and lack of success of Black men in college is more pronounced than in any other student group" (Leach, p.1).

African American College Enrollment Rates

Characterizing Black males as an endangered species makes some sense when looking at the daunting statistics on Black males in higher education. Between 1980 and 1996 the number of Black females enrolled in higher education rose by $33.1 \%$, more than double the increase for Black males (Cross, 1997). In 1997, 35\% of all Black males in the age group of 18-24 were enrolled in college, compared to $43.6 \%$ of Black females in the same age group. Although the gap narrowed in 1998, the disparity still remained; the college enrollment rate for Black males was $38.2 \%$ and $42.4 \%$ for Black females; the corresponding enrollment rate for White males was $44.3 \%$ compared to $45.9 \%$ of White females (Gordon, 2002). In 2003, 25\% of young Black males went to college, as compared to $35 \%$ of Black females (Cose, 2003). Although women are enrolling in college at much higher rates than men, as of 1995 African Americans are the only group in America in which females outnumber males 800,000 to 500,000 in college enrollment (Kunjufu as cited in Hawkins, 1996). Taken together, this data clearly indicates that there still remains an ominous gender disparity in the enrollment of Black students in higher education that has continued since 1980 .

\section{College Graduation Rates}

As daunting as these statistics are, there is an equally alarming trend involving the number of African American males graduating and attaining a college degree compared to African American females. 
In 1989, 22,370 African American men were awarded bachelor's degrees compared to 35,708 African American women, but in 1998 the numbers were 34,469 degrees earned by African American men and 63,663 by women, and the gap between these groups continues to expand. (Harvey, 2003, p.21)

In 1990, of those students who were seeking a bachelor's degree by May 1994, $43.5 \%$ of Black females, compared to $34.4 \%$ of Black males actually attained a bachelor's degree (Nettles, M. \& Perna, L., 1997). In 1997, the percentage was still somewhat consistent; $33 \%$ of Black males graduated, as compared to $43 \%$ of Black women. Additionally, the number of Black males in the general population who were college graduates and beyond was $14.2 \%$ in 1999 , compared to $16.4 \%$ for females in the same time period (Johnson, 2002).

The gender disparity among Black degree attainment is across all higher education categories; according to a recent article in the Journal of Blacks in Higher Education, women earn $67 \%$ of bachelor's degrees awarded to Blacks, $69 \%$ of master's degrees and $66 \%$ of doctoral degrees awarded (Hong, 2002). For example, in 1995 the percentage of PhD's awarded to Black females exceeded the percentage for Black males. For Black females it increased from 686 in 1994 to 805 in 1995, and for Black males the increase was from 409 in 1994 to only 482 in 1995 (Hawkins, 1996). Even more disturbing are current statistics that indicate that Black women posted a $5.6 \%$ increase in the number of doctoral degrees awarded in 2000, compared with a 1.3 decline for Black males (Nineteenth Annual Status Report on Minorities in Higher Education, 2001). If this trend would continue at the same rate, by the year 2097, Black females would earn all bachelor degrees received by African Americans (Cross, 1997). 


\section{Attrition Rates}

As discussed previously, statistics clearly indicate that the gap in degree attainment exceeds the discrepancy in enrollment rates for African Americans. This discrepancy is, therefore, an indication of a problem with attrition for African American males; according to Leach (2001), the rate of attrition among African American males is disproportionately higher than for African American females and degree completion is disproportionately lower than for African American women.

When comparing races, Clayton (2001) finds that minority males not only drop out at higher rates than White males, but are harder to recruit. For example, the most recent statistical data available from the African American Data Book (Nettles \& Perna, 1997 ) indicates that of those students enrolled in college in 1990 , nearly $53 \%$ of Black males left college in their freshman year compared to $44.5 \%$ of Black females. This is compared to $39.3 \%$ of White males and $40.8 \%$ of White females in the same time period. In addition, $35 \%$ of Black males left college without returning to school at all compared to $32 \%$ of Black females in 1990 . This can be compared to $28.5 \%$ of White males and $35.1 \%$ of White females in the same time period.

Statement of the Problem

Many researchers and educators are puzzled by the continual decline of Black male enrollment and graduation rates from institutions of higher education. This discrepancy, as noted by Washington and Newman (1991), is less a consequence of the significant increases of Black women as it is the decline for Black men. The substantial discrepancy in college enrollment and degree attainment for Black males versus Black 
females poses many threats to the Black community and is, therefore, problematic for Black males and females as well as society as a whole.

The lack of educational attainment for Black males has ominous effects on the development of the Black community (Washington \& Newman, 1991). For example, a college education would afford most Black males the opportunity to experience significant intellectual development, as well as acquiring the necessary preparation and credentials for employment opportunities. According to Harvey (2002), receiving a bachelor's degree increases a persons "earning power" and enhances the "social standing that comes along with it" (p.21). Therefore, if Black males are not receiving college degrees, they are faced with the arduous task of locating and keeping a job in a competitive society where the majority of high paying jobs require a college degree. The employment opportunities that relatively uneducated Black males do receive will provide them with less political or social capital to have their voices heard and contribute to policy-making decisions that affect not only society, but the Black community as well. Without a college degree it is unlikely that Black males can be an influential change agent; and according to Washington and Newman (1991), in the past many Black leaders developed and practiced their leadership skills through college activism, an arena that has proven to be an effective starting point for local, state, and federal change agents (p.30). Washington and Newman (1991) also report that the "imbalance of Black males and females both in and out of college may reinforce dysfunctional behavior and genderdirected hostility in college". They assert that "as a result of Black males losing their educational and economic ground, some Black men disrespect their coed peers, sometimes in exploitative or abusive ways" (p.31). In addition, the gender disparity in 
college graduation rates limits the opportunity for females to establish long-term relationships with Black males of similar educational backgrounds and, therefore, potentially decreasing the probability that Black females will find college educated Black males. Research indicates that of Black females with college degrees who married, only $45.9 \%$ of their husbands had a college degree (Cross, 1997). Studies also indicate that many college-educated Black women are avoiding marriage all together. For instance, in $1996,27.6 \%$ of all college-educated Black women over the age of 25 have never been married (Cross, 1997); and according to the 2000 Census, $47 \%$ of Black women in the 30-to-34-age range have never married, compared with $10 \%$ of White women (Cose, 2003). Undoubtedly, this "choice" has something to do with the availability of Black males with comparable educational backgrounds. According to Gordon (1999), "indeed male marginalization has substantially reduced marriage among African Americans" (p.164). Comparatively, Washington and Newman (1991) state that in the absence of a pool of well-educated African American men, women are likely to remain single or seek out alternative means of succumbing to the societal pressures of marriage.

Given the compelling evidence that an educational attainment gap within the Black community exists and the long-term negative effects that this gap has on both Black males and females, it is surprising that there is such a dearth in the literature on this topic. There is limited empirical research that attempts to explain why Black males and females are graduating from colleges and universities at such disproportionate rates. Although there are theories outlined in the literature about the disparity between Black males and females that may provide some explanation as to the discrepancy in college 
attendance and graduation rates, empirically-grounded knowledge about the existing gap between Black males and females is still ambiguous and more research is clearly needed.

The theoretical literature, however, does identify several factors that may contribute to the problem minority student's encounter at PWI's that may contribute to students withdrawing from the university. The literature, for example, suggests the importance of looking at within-institutional factors such as faculty-student relationships, social integration and academic self-efficacy as a means of understanding the environmental factors associated with student persistence in college. These factors, as suggested by several researchers including, Tinto (1988), Berry and Asamen (1989), and Fleming (1984), are important to examine when trying to make sense of the differential success rates of Black students in college.

When examining these factors, it is important to focus on how students perceive institutional factors and how these perceptions may relate to student withdrawal from the university. Perceptions play a significant role in how we perform in certain situations. Students' perceptions of the college environment as well as their interactions with the campus, exerts a strong influence on academic achievement (Armstrong \& Carty, 2001), and their psychosocial development in many domains (Pascarella \& Terenzini, 1991). People respond to a situation, not necessarily as it "really" is, but as they "perceive it to be" (Newcomb, 1966, p. 3). Therefore, it is important to examine how students perceive their college environment, particularly African American students, and how these perceptions relate to the existing educational attainment gap between the two genders.

To date, however, most of the literature, as well as studies related to the gender disparity among Blacks, have provided little empirical data on the perceptual differences 
of campus climate as defined by institutional supports, social integration and selfefficacy. Most studies do not focus on student perceptions as they relate to gender, but on the cognitive factors related to race and comparative studies of African American and White student achievement. For example, many studies have focused on the differences between African American and White students at predominately White institutions in regards to assessing progress made by the two groups, barriers to graduation, and factors that influence attrition. Additionally, studies have been conducted on Black students' expectations as they enter a PWI (Kim \& Sedlacek, 2003); academic and noncognitive factors affecting Black males (Tracey \& Sedlacek, 1985); and Black students' perceptions of their needs at PWI's (Rowser, 1997). Much of the findings, however, from these studies and others have not focused on the distinction between Black males and females' perceptions of campus climate at PWI's and how these perceptions affect attrition. Therefore, what is less understood is how environmental forces influence the way in which Black males and females come to perceive the school experience and how those perceptions influence their academic performance in school.

There has been little work in the area of gender perceptions of campus climate among Black students. According to Davis (1998), "without focusing on how gender often circumscribes academic and social outcomes, we are less informed of the institutional strategies aimed at integrating all students into the mainstream of campus life" (p.6). Similarly, Hood (1992) states that non-traditional variables such as student perceptions continue to gain credibility in their relevance to the persistence and academic success of minority students. Additionally, Nora and Cabrera (1996) in their study state that perceptions, particularly about racial climate, may "lower the quality of college 
experiences of minority students" and thus affect persistence rates (p.120). Davis (1998) concurs and states that perceptions of racial climate influence Black students' academic experience and performance at PWI's.

Thus, the importance of understanding the differences in perceptions of campus climate between Black females and males may help us better understand why Black females earn far more college degrees than Black males. Therefore, one aspect of this study that can potentially add to the current body of knowledge is an exploration of whether or not Black males and females perceive campus climate at PWI's in different ways.

\section{Purpose of the Study}

The primary purpose of this study was to explore the impact of gender on African American students' perceptions of campus climate at one PWI. This study was an attempt to quantitatively determine whether a relationship exists between gender and African American students' perceptions of campus climate.

This study focused on the measures of perceptions of three aspects of campus climate: social integration, institutional supports, and self-efficacy. As noted in the previous section, these three aspects of campus climate have been identified in the literature as important factors that influence college persistence. Thus, this research looked at whether African American males and females had different perceptions of campus life related to these three factors and how those perceptions may contribute to the educational attainment gap in the African American community. In addition, the study examined other aspects of college life that could possibly influence students' perceptions of the campus climate. These factors include involvement in extracurricular activities, 
working on or off-campus, students' academic performance in high school and other variables that have been articulated in the literature as possible contributing factors to student persistence in college.

Information regarding students' perceptions of campus climate has been gathered and the analysis of the data extracted from the three measures of campus climate previously mentioned, as possible influences on the persistence of African American males in higher education.

\section{Research Questions}

The research questions for this study were designed to explore how African American students perceive the college campus at a PWI and how those perceptions may possibly affect persistence and graduation rates in higher education. The research questions served as a guide to support a quantitative study at one PWI:

1).What perceptions do African American undergraduate students have about the campus climate?

2). To what extent are these perceptions a function of gender?

3). To what extent are the perceptions of campus climate a function of other factors (i.e., high school GPA, parent's income level, students living arrangements, work hours, affiliation with a sorority or fraternity, etc.)?

\section{Significance of the Study}

This study examined the extent to which gender has an influence on African American students' perceptions of campus climate. This research will provide possible reasons why African American females are more inclined to complete college than African American males. The data gleaned from the study may possibly help identify 
strategies, programs and interventions that can influence policy-making decisions to support African American males at PWI's. The results of this study will contribute to our understanding of intra-racial perceptions of campus climate. Moreover, administrators in higher education will be better informed of the perceptions of campus climate as perceived by African American students, and thus may be more likely to implement appropriate programs that support Black males at PWI's in those areas of campus climate where students feel least supported. The goal of the study was to analyze undergraduate African American students' perceptions of campus climate at a predominately White southeastern institution, which may result in changes to existing policies and practices utilized for retention of African American male students in higher education.

\section{Limitations of the Study}

While the results of this investigation can suggest possible reasons why Black females and males graduate at different rates, the study is clearly limited to a single institution and should not be generalized to other African American students at other institutions of higher education without caution. The population of students attending this university may be vastly different than African American students at other settings.

The study also used a single method approach that limits the view on the complexity of the perceptions and behaviors measured. Without triangulating the findings the perceptions may be biased or provide a distorted view of the participants.

Another limitation is that students without an active email account were not part of the sample selection. However, since this applied to only a small number of individuals, the assumption was made that any potential bias arising from not having an 
active e-mail account would be minimal and as such, would not significantly distort the result of my study.

Another limitation to the study is the possibility of sampling bias. Students who dropped out of school and transferred prior to the questionnaire being distributed were eliminated from the sample. Also, since the respondents self-selected into this study, they may not adequately reflect the population of African American students at the studied institution. For example, responding students may have been those who were already socially integrated within the university and more academically involved, thus more apt to contribute to the study for their own personal interest. Additionally, students who participated in the study may have been more comfortable with, and knowledgeable about technology and their ability to access the on-line link to the survey.

Lastly, given the small sample size of Black male students (87), compared to females (279), the differential perceptions may be skewed given the disproportionate number of male respondents. Therefore, the findings should be interpreted with caution. 


\section{Chapter Two}

\section{REVIEW OF THE LITERATURE}

This chapter presents a foundation for the study through a review of the related literature and research. The literature review provides a conceptual framework for understanding factors that influence college persistence among students and how these factors affect African American student attrition, and in particular the significant gap that exists between African American males and females. The body of research on college persistence and retention spans several decades with much of the literature focusing on Tinto's $(1988,1987)$ theory of student departure from institutions of higher education. Pascarella and Terenzini's (1991) findings on the influence of college experiences on student development. Tracey and Sedlacek's (1985) assertion of the relationship between non-cognitive variables and academic success. Fleming's (1984) empirical studies on Black intellectual development in White institutions. Astin's $(1975,1984)$ research on student involvement. Polite and Davis' (1999) research on Black males in society. Irvine(1990) on Black students and school failure, and Bandura's (2000) theory of selfefficacy as it relates to the success and failure of college students.

\section{Theoretical Frameworks}

There are three broad topics that frame the existing research and are particularly relevant to the study of African American students in institutions of higher education, especially African American males. The frameworks include an historical perspective of the education of African American males, such as employment opportunities, elementary and secondary education, and incarceration affects. Studies on the effect of institutional and social supports on African Americans at PWI's will also be examined as well as 
African American students self-efficacy beliefs and how these beliefs affect educational aspirations. Each broad topic will help to explain the antecedents of Black males' education as it pertains to pre-college determinants as well as institutional supports that have a significant effect on students' educational attainment by shaping their social and academic experience at college.

Historical Perspective of African American Males in Education Is it possible that the large and growing gender gap between African American males and females in higher education can be traced back to the effects of primary education, and the covert yet pervasive discrimination in employment opportunities? As poignantly quoted by Gibbs (1988), "Blacks in this country are victims of a legacy of nearly 250 years of slavery, 100 years of legally enforced segregation, and decades of racial discrimination and prejudice in every facet of American life" (p.17).

Given the salient factors that have oppressed African Americans in this country for many years, what factors have influenced the discrepancy in the educational attainment in higher education between Black males and females? Perhaps, we can trace it back to slavery where years of enslavement brought on the annihilation of Africans and the separation of Black families. This, consequently, forced Black women to take on many of the family responsibilities that are traditionally held by men; and over the generations a long tradition of strong, capable women has developed in the Black community (Cross, 1999, p. 8). The evidence is clear, that despite the barriers faced by African Americans, "Black females are overcoming the obstacles in far greater numbers than Black males and are doing so at every level of the educational hierarchy" (Cross, 1994, p.49). Therefore, although slavery may be a plausible theory explaining the onset 
of unfair educational practices of African Americans, what are some other explanations of the abiding plight of Black males in education, and most importantly, the educational gap in the African American community?

\section{Employment Opportunities}

A review of the literature suggests that the gender gap between Black males and females has been steadily increasing for the past 20 years. According to Cross (1999), a primary reason for this gap may be a result of earlier employment opportunities. In the 1960 's and 1970's Black men were less likely to pursue higher education because they felt as though it would not lead to increased opportunities for employment during a time of segregation; instead of attending college they settled for menial jobs. Black women on the other hand, had more of an incentive to pursue higher education. As a result of the invasive school segregation, there were many jobs available for Blacks as schoolteachers; a profession concentrated by women. It has, therefore, been suggested that the gender gap in the African American culture is a result of the initial lead in college degrees earned by Black women, compared to Black men (Cross, 1999).

According to an article in the Journal of Blacks in Higher Education, the media's portrayal of successful Black males concentrates on athletes, musicians, comedians and other entertainers. These, of course, are all occupations that require little or no formal education (Cross, 1994). However, many Black males place emphasis on these professions, and this "sends large numbers of young Black males down a career blind alley" (Cross, 1998). According to Hong (2002) many Black males do not see Black doctors or lawyers; and are often times exposed to Black males portrayed as dancers, singers, and rappers. This ultimately becomes a one-track road to success that many of 
them try to emulate. Success for Black males seems to be promoted in two ways: music and sports; and are somehow perceived different if they pursue careers in "law or medicine because of this media portrayal" (Hong, 2002, p.1). In a 1986 study, Fordam and Ogbu (as cited in Irvine, 1990) state that "children respond positively if they observe that older people in the community usually obtain jobs and other societal benefits commensurate with their schooling (p.4). As asserted by Polite and Davis (1999), we find particularly distressing the multiplicity of problems facing adolescent males in urban America, such as gangs, negative peer pressure, anti-schooling attitudes, and drug trafficking, these often obscure the diversity and complexity of African American males' experiences in school and society. (p. 5)

Another plausible reason why Black males are less represented in college is that within the past few years the robust economy has offered Black males gainful employment from high school. Individuals with technical skills were in particular high demand and many African American males decided to take advantage of these opportunities rather than attend college (Gordon, 2002).

Discriminatory practices have also been noted as a major culprit in the differences in educational attainment of Blacks. According to Polite and Davis (1999), discrimination negatively impacts African American males, in particular. Evidence suggests that racial discrimination in the 1950's and 1960's has influenced the participation of males in higher education because of decreased employment opportunities. Black males, therefore, entered the work force usually in menial positions or as laborers (Cross, 1999).

Discrimination has negatively affected Black males more so than Black females in the job market. There is a tendency of employers to place greater value on African American 
female employees than on men, contesting that Black females benefit from the notion of being a "twofer", or double minority. This advantage, of course, encourages Black women to pursue higher education much more eagerly than Black males (Cross, 1999). According to a report on the Black population in the United States, Black women are 62 percent more likely to be employed than Black males (BET, 2003). And, among collegeeducated men with college degrees, 1 out of 9 African American males was unemployed compared to 1 out of 29 for White males (National Urban League, 1998).

These daunting statistics have implications on Black males' motivation and desire to pursue higher education with the likelihood of not attaining a job.

\section{Elementary/Secondary Preparation}

Pre-college preparation has also been a very strong determinate in the educational attainment gap of Black males and females. It is vital for youngsters to have a foundation in the early years of schooling. Elementary and middle schools have a responsibility to edify our youth and support them for future success in school and society. Gordon (2002) states that the roots of under-achievement can be traced back to the beginning of school. He reports that from a "recent national data study of beginning kindergartners, it shows conclusively that African American males lag behind other groups with respect to emergent reading and mathematics skills" (p. 2). According to findings from 10 years of longitudinal research on students, Choy (2002) states that there is a positive relationship between taking challenging mathematics courses and going to college. As a result of African American males lagging behind in mathematics and reading skills, they are more susceptible to being identified as special education students. In fact, it has been stated that males, regardless of race, exhibit lower reading and writing scores, and are therefore 
more likely to be placed in special education classes (Gordon, 2002). As a result, Black males are at a disadvantage of carrying the burden of the risks associated with both race and gender. One of those risks is a lack of successful Black role models in the home as well as in schools. According to Cross (1995) the lack of Black male role models brings on a more acute risk for males than females. In fact, two thirds of Black male babies are born to unwed mothers, and as a result of the large female- headed households, there is no stable male parent to instruct boys on the quality of education (Cross, 1995). Consequently, this lack of knowledge about the importance of education in father-absent households can be pernicious to African American boys and can possibly affect their academic performance. Lynn, (as cited in Gibbs 1988) suggests that children living in father-absent homes are more likely to exhibit lower scholastic performance. Role models, especially for African American boys are an important aspect in schools; however, it is clear that despite many efforts made by school officials, Black male teachers are scarce. For example, according to Washington and Newman (1991), the dominance of elementary and secondary education by women diminishes the number of role models in the school for Black males. Eighty-three percent of elementary teachers are women, and $0.2 \%$ Black males. Forty-six percent of secondary teachers are women, and only $3.2 \%$ are Black males. As a result, many Black males rely on their peer group for learning values and appropriate behavior, and as a consequence Black males may perceive academic achievement as a feminine process. (p. 23) 
Similarly, Kuykendal (1992) asserts that

Black students have a strong need for achievement and approval, and very often these needs are satisfied in peer groups where rapport is established and bonds are made.... In a comparative study of self-perceptions among Black girls and boys, self-image of Black boys depended on non-academic factors such as peer acceptance. The self-image of Black girls was related more strongly to academic achievement. (p.21)

\section{School Organization/Teacher Expectations}

The culture of the education system appears to support young Black girls over Black boys, and usually sees boys as discipline problems (Johnson, 2002). A result is that many Black males are disproportionately placed into special education classes where they are more likely to be classified as incapable of serious academic pursuit (Cross, 1995). Similarly, Leach (2001) asserts that

African American males are more likely to be placed in classes for students with learning disabilities than in gifted and talented classes, and are far more likely to be placed in general education and vocational curricular tracks than college-bound tracks. (p.1)

In addition, Black males drop out or are pushed out of school systems at higher rates than other ethnic/gender groups. They are suspended from school more frequently and for longer periods of time than any other ethnic/gender groups; and complete high school at significantly lower rates than any other ethnic/gender groups. In fact, in a recent research study conducted in 2001-2002, 41\% of African American males graduated with 
their high school classes compared with $70 \%$ of non-Hispanic White male students (Gewertz, 2003, p.2).

The preponderance of Black boys in special education classes can be attributed to the attitudes and expectations of school personnel; many of whom place these students unfairly and with partial understanding of their potential (Gordon, 2002). Many teachers have preconceived notions of students' academic abilities, and this may be a result of racial stereotyping. This stereotype is, therefore, dangerously linked to punitive responses; and thus, Black males form an anti-achievement ethic (Gordon, 2002). As posited by Irvine (1990),

the distinct African-American culture can result in lack of correspondence between Black students and their teachers particularly as it relates to Black students' presentation of self, their language and their ways of knowing and processing information. The decreasing numbers of Black teachers and principals will contribute to a lack of synchronization between teachers and Black students. (p.42)

Similarly, Kuykendall (1992) purports that both Black and White teachers perceived that schools and schooling valued neatness, conformity, particularly concepts of beauty or appearance, attitudes, language, and behavior. Both White and Black teachers viewed Black males as most negatively "different" from the valued characteristics. (p.32)

Additionally, lowered expectations from teachers, counselors and administrators, result in the alienation of Black males and make failure an all too common part of their educational experience. Black males begin to "behave according to teachers' expectations 
and their behavior then reinforces what teachers think about their abilities" (Cross 1999, p. 8). This, of course, can be pernicious to students; it decreases students' self confidence as well as lessens his opportunity to showcase his true potential. In a recent article in National Education Association, a study conducted on 40,000 middle and high school students reported that "nearly half of Blacks said they worked hard in schools because their teachers encouraged them, compared with 30 percent of Whites (Ferguson, 2005, p.23). Also, Flannery and Jehlen (2005) assert that if kids feel teachers have low expectations for them often times kids will seek to meet those low expectations. According to Steele (1992), many Black males "disidentify" with school and academics. Disidentification, as defined by Steele is "the lack of a relationship between academic self-esteem and global self-esteem, with the implication that there has been a relationship in the past" (p. 2). Often times, Black youth disidentify with school because they are often accused of "acting white". Many Black male students who make an attempt to do well in school are frequently ridiculed or ostracized by their peers" (Cross, 1997, p. 85). Similarly, Steele (1992) posits that Black males often feel devalued on their efforts, and this devaluation often affects their identification with school. Black males, then, begin to "undercut the identification with schooling, either before it happens or after is has bloomed" (p. 4). Similar to Steele's assertion, Gordon (2002), states that some believe that hip-hop culture, which is indigenous to young African Americans has championed a set of values and attitudes that manifest socially rebellious behavior and success in the classroom environment is ridiculed as "acting white", and that the effect of this negative pressure reduces the 
opportunity for African American males to compile the kinds of records of achievement that facilitates college participation. (p. 19)

Another explanation for the underachievement of Black boys in school is their identity of self. Polite and Davis (1999) contend that many Black males perceive educational experiences as irrelevant to their development (p. 3). And, Davis (2003) further explains that it is important for schools to have an "increased presence of committed and successful Black male adults in educational environments to enhance Black boys' academic and social identity development" (p.527). According to Kuykendall (1992), social and academic image of Black boys is an important determinate of how they feel about themselves, how they speak and present themselves. She further asserts that it is the academic self-image that dictates how well children fare in their academic competencies, and that this image is molded in the classroom. In a 1985 study of Black children on the Comprehensive Tests of Basic Skills in the District of Columbia Public Schools, it was found that as Black children mature, they begin to experience many hostilities imposed by the majority culture. Such hostilities often are rooted in the inability of teachers to augment the academic self-image of these youth. (p.23)

\section{Incarceration Effects}

The issue of crime, violence, and imprisonment is a pervasive problem that is often times perpetuated by the media. Black males are often times stereotyped as the individuals that commit the most crime. Gordon (2002) asserts that "through the multimedia age of information, the Black male has been stripped of his right as a viable citizen to that of a menace to society" (p. 41). Statistics indicate that 30 percent of all Black 
males in the United States are either in prison, on parole or probation, as of 1995. Black males born in 1991 , stand a $29 \%$ chance of being imprisoned at some point in life compared to $4 \%$ for a White males, and Black males represent only $3 \%$ of the college enrollment and 47\% of American prisoners in 1992 (Jones, 2002). According to the Bureau of Justice Statistics, in 2001 the prevalence of imprisonment in the United States was higher for African American Males at 16.6\%, and for Black females it was 1.7\%; and the characteristics of jail inmates are estimated to be $40 \%$ African American. With this over- representation of Black males in prison, this lessens the opportunity for Black males to enroll in institutions of higher education.

In 1992, Diluio (1994) reports that the crime victimization rate for Blacks was the highest ever recorded. For example, the violent crime victimization rate for Black males between the age of 12-19 was 113 per 1000, compared to 94 for Black females, 90 for White males and 55 for White females in the same age category. Additionally, "the crime in America is predominately intra-racial, and not interracial- about $84 \%$ of singleoffender violent crimes committed by Blacks is against Blacks" (Dilulio, 1994, p.16); and it "appears that Blacks are more likely to be imprisoned where they are a smaller, politically weaker, and economically marginalized population" (Oliver, 2001, p.31). As a result of these formidable statistics, a larger percentage of Black males, than females, face daunting experiences in society that not only impede and discourage any hope of pursing higher levels of education, but eradicates their very existence in society.

\section{Conclusion}

It is quite clear that these data represent a formidable outcome for Black males in America's schools as well as society. With the initial lead in degrees by Black females; 
the discriminatory practices institutionalized in the work place; the susceptibility to academic tracking and misconduct in elementary and secondary schools; and the dangers of crime and imprisonment has indubitably placed Black males at a disadvantage in pursing and attaining a college degree compared to their Black female counterparts.

$$
\text { Within- Institutional Support Systems }
$$

\section{Student Supports}

According to Tinto (1987), "student departure is more a function of what goes on within the institution following entry than what may have occurred before hand" (p. 202). As stated by Lang (1992),
a blatant fallacy is the notion that low college entrance scores or college entrance scores themselves are the best measures and predictors of intelligence. These scores measure at best what one has already learned both in and out of school, not one's intellectual capability or capacity to learn. (Lang, 1992, p.517)
Therefore, researchers refer to the importance of looking at within-institutional factors, such as faculty student relationships, academic counseling, and financial aid supports as possible indicators of effective matriculation into college, and consequently academic success.

Historically, academic success was understood to be related to a lack of ability or poor study habits. However, according to Tracey and Sedlacek (1985), growing evidence suggests that non-cognitive variables such as dealing with racism and having a strong support system in college are also important and, in fact, even more important to academic success than are the traditional academic dimensions, especially for minority students (p.405). Consistent with this finding, Hood (1992) found that nontraditional 
variables continue to gain credibility to the persistence and academic success of minority students.

Studies investigating locus of control, students' perceptions, expectations, and environmental stressors, academic and social integration, social isolation, academic and institutional investment, racial identity issues and faculty and peer expectations have all concluded that nontraditional dimensions account for as much or more of the variance in retention rates, particularly for minority students. (p.13)

The first year of college is a critical year for retention; therefore, all students entering school should be provided the necessary support systems to matriculate into college and persist until degree completion. Once on campus, institutional supports such as students' academic counselor, financial aid, and academic faculty can contribute to a successful entrance into a new environment. If institutional supports are easily accessible to the student as he or she enrolls, the transition into school is much easier. For example, a study conducted by Pascarella et al. (1986) on the effects of an orientation program to incoming freshmen as a form of anticipatory socialization showed that an orientation program was a potential facilitator to effectively helping students to matriculate into college. This is especially true for African American students at PWI's where a supportive environment is important. For example Davis (1998) found that students who perceive a supportive campus climate are less likely to avoid informal contact with faculty and administrators than students who don't perceive a positive climate. Consequently, faculty and administrators respond more 
actively to African American students who foster informal contact with them, and this relationship affects academic performance both directly or indirectly. (p.4) Allen (1992) suggests that researchers have more of an understanding of campus relations as explanations for differential achievement by African American college students. For example, Black students' academic difficulties at PWI's are often compounded by the absence of remedial/tutorial programs and a limited informal information exchange with White faculty and students. However, it is important to note that "the separation created by special assistance programs should also be tempered by opportunities to grow out of the need for extra assistance, and the programs themselves should not be self-perpetuating" (Boyd, as cited in Sherman, et al., 1994). Although tutorial programs are needed, many African American males do not perceive a need for assistance. For example, a study conducted by Rowser (1997) on entering African American students' perceptions of their needs indicated that almost three times as many females than males perceived a need for tutoring, 45 percent, and 16 percent respectively. In addition, according to Kim and Sedlacek's (2003) study on African American students' expectations at PWI's, found that "more African American females than males expressed that college course work would require a significant amount of concentration and studying and that courses would be simulating" (p.7). The disparity, of course, may result in Black males being less likely to ask for academic assistance when needed as well as spending less time with their academics. Conversely, Gibbs (as cited in Lang \& Ford, 1992) concluded that Black students in the initial college years use formal help sources and seek academic counseling more than any other type of help and they are "three times more likely than Whites" to use academic services offered by the institution 
(p.31). This finding supports the effective use of tutorial programs and the importance of the availability of academic assistance for Black males. Sherman et al. (1994) investigated possible factors that may predict college dropout and found that "student retention is generally addressed in tutorial programs, peer counselors, minority student programs and a variety of efforts to assist in career, study skills, and financial and personal problems, especially for Black students to remain in school after the first year". (p.168)

\section{Faculty and Student Relationships}

The academic environment at college can be a challenging endeavor; however, faculty and other academic staff can play a significant role in facilitating students' academic performance. For example, Allen (1992) investigated the relationship between the student outcomes of academic achievement, social involvement, occupational aspirations, students' educational background, educational goals, demographic characteristics, personal adjustment to college, and the college environment. In this study, Allen found that one of the reasons for high academic achievement was that students with high educational aspirations had reported positive relationships with faculty. Consistent with this finding was a study conducted by Pascarella and Terenzini (1980) who used the Tinto model to predict freshman persistence and voluntary dropout decisions. They found that both formal teaching and informal non-teaching roles of the faculty had an influence on freshman students' decisions to persist or withdraw from a particular institution. In fact, the study found that "student-faculty relationships were more of a predictor of decisions to persist or withdraw then students' peer relationships" (p. 72). According to Lang (1992), student-faculty interaction encourages students to 
"study more, which enhances retention. The frequency of students' informal contacts with faculty outside of class is positively associated with persistence and learning" (p.29). Similarly, Astin's (1984) theory of student involvement states that the interaction with faculty is more strongly related to satisfaction with college than any other types of involvement or, indeed, any other student or institutional characteristic. Students who interact frequently with faculty members are more likely than other students to express satisfaction with all aspects of their experience including student friendships, variety of courses, intellectual environment, and even the administration of the institution. (p.304) The implications that Astin's theory of student involvement has on Black males is that student-faculty relationships are an important indicator of how well Black males perceive the campus climate and their satisfaction with the university. For example, Gonsalves (2002) conducted a study on the communication between White faculty and Black males and found that

Black students described the faculty as not caring at best and racist at worst; and found that when the racial climates were too intense many White faculty became overly rigid in enforcing their classroom standards or made allowances for Black students that real learning never took place. This, then, compromises the success of Black students. (p.436)

Jones (2001) asserts that students are sensitive to the climate in their classes and that "students know in which classes they will find a supportive atmosphere, a respect for cultural difference, higher expectations, and positive role models" (p.10). The Gonsalves' study suggests that institutions provide opportunities for faculty to reflect on racial issues 
that may affect classroom performance, because this may be a contributing factor to persistence.

\section{Financial Aid}

Another component related to institutional supports is financial assistance for students while attending college. Willie et al. (1991) state that financial aid is an essential component to Black students college attendance. Data indicate that those students without financial assistance are more often the ones who leave (Berry \& Asamen, 1989). Similarly, Jones (2001) states that the contribution to successful persistence and graduation of African American students is that of adequate amounts and types of financial aid. Financial aid is often the primary consideration in making the decision to continue or leave (p.9). Therefore, colleges and universities have a responsibility not only to see that students obtain the necessary financial assistance but also to provide academic and social counseling to help them matriculate and receive their degrees (Willie et al., p. 98). Sherman, et al. (1994) concede that one consistent predictor in all the reviews of dropout is financial concern. "Financing college studies is a clear and effective measure to promote retention" (p. 166). Consistent with this view, Boyd (as cited in Sherman et al., 1994) found in his 1974 study, "finances were, and continue to remain, a major concern for Black students" (p.171). Boyd also asserts that the predictability of financial aid for Black students should be increased and that the emphasis on loans in the aid package is often increased to those students whose family income falls below identified levels such that repayment is almost impossible. Students who worry about having the financial assistance to complete their college education can encumber their academic performance. (p.171) 
Consistent with Boyd's assertion, Tinto (1987) states that "changes in financial status may lead directly to departure when changes prevent the individual from meeting the minimum financial requirements of institutional participation" (p.81). Gibbs (1988) also studied the effects of financial variables on student drop out and found that "college persistence rates are associated with financial circumstances, and Black students are more likely than Whites to leave college for financial concerns. And, among four-year college students, 38 percent of Black students not receiving financial aid withdrew for nonacademic reasons as compared to 23 percent of their White counterparts" (p. 69). Similar to this finding, Fleming (1984) has argued that the lack of support services, financial problems, and the nature of interpersonal relationships with faculty and academic staff are some of the experiences that negatively impact minority students attending predominately White institutions. Additionally, Dubrock (2000) concluded from his study of financial aid and college persistence at Arizona State University that "receipt of financial aid was consistently a positive influence on persistence and is especially significant in the second and third years of college. He also found that "financial aid promotes year to year persistence" (p.3).

As stated by Willie et al. (1991), the success of Blacks in college in the twentyfirst century will be the result of several issues being resolved, one of which is increasing institutional supports at colleges and universities to reduce attrition rates.

\section{Social Integration}

In addition to institutional supports, another critical component to the success and persistence of students in college is how well they are socially integrated into the university. Researchers have examined how social integration and students' 
"involvement" in college affects their academic achievement and persistence, and how "institutional fit" is an important element in fully integrating into the university, (Tinto, 1987).

Social integration is characterized by a "sense of belonging and feeling part of the social life of the university, and those students who are socially integrated are more likely to persist, leading to retention and graduation" (Lang, 1992, p. 39). Students who are socially integrated are "involved" in the institution. Involvement refers to the "investment of physical and psychological energy in various objects, and this object may be highly generalized to student experiences" (Astin, 1984, p. 298). Astin asserts that "the amount of student learning and personal development associated with any educational program is directly proportional to the quality and quantity of student involvement in that program" (p.298). According to Astin's (1984) theory on student involvement, the greater the student's involvement in college, the greater will be the amount of student learning and personal development" (p. 307).

Several researchers have discussed ways in which students can have adequate involvement within the university. Tinto (1988) states that students who become adequately integrated into the social system of their college through extra curricular activities and interactions with other students, develop a stronger level of commitment to attaining a college degree. Tinto's "rites of passage" as articulated in Christie and Dinham (1991), describe that to become fully integrated into the college community, students must

move from membership in one community to membership in another through three related and interactive mechanisms: separation from past communities, 
transition into new college community through learning the values and expectations of that community, and incorporation into the college community through actually adopting the norms and behavioral patterns of the new community. (p. 413)

Additionally, Tinto (1988) states that separation from the past is stressful, especially for those students whose colleges are markedly different in social and intellectual orientation from which characterizes the family and local community. In order for these students to become integrated they must disassociate themselves physically as well as socially from the communities of the past (p. 443). Conversely, in a study by Nora and Cabrera (1996) on the role of perceptions of prejudice and discrimination on the adjustment of minority students to college, found that attachments to family, friends and past communities are key to a successful transition of students to college; "parental encouragement and support was found to have a positive affect on the integration of students to college, on their academic and intellectual development and on their academic performance and commitments - both to completing a college degree and to the institution itself' (p.140).

Christie and Dinham (1991) conducted a study based on the institutional and external influences on social integration in the freshman year and found a strong link between living on campus and participation in extracurricular activities and becoming more socially integrated. Students who lived on campus had more of an opportunity to gain information and participate in social events on campus; if students were involved with extracurricular activities, they were more likely to meet and develop friendships with other students. Conversely, students who lived off campus and who had high school friends who were not part of the university were less likely to be socially integrated than 
students who lived on campus. In fact, students who lived on campus felt that "interaction with their high-school friends interfered with their "involvement" in the university" (p.424). Pascarella and Terenzini (1980) found that "living on or near campus facilitates integration into the campus social network of peers, faculty, and extracurricular activities which has positive implications for persistence and degree completion" (p.401). Astin's (1975) study on the environmental factors in college that affect student persistence found that the student's residence was the most important and pervasive environmental factor that affected student involvement. Moreover, living oncampus was positively related to retention, and this positive effect occurred in all types of institutions and among all types of students regardless of sex, race, ability or family background (p. 302).

Social involvement in college may be an easier transition for some students than others.

As students begin to develop socially in the university, they must learn to adopt values and behavioral styles congruent with the university, and those students who are from families, communities, and/or schools, which are very different in behavior and norms from those of the college, are faced with especially difficult problems.

(Tinto, 1988, p. 445)

For example, African American students often are challenged at predominately White schools because there is a small number of minority students with whom to associate and identify with. Fleming's (1984) research on Blacks in college described African American students as having feelings of stress related to racial tension and they are more 
likely to have inadequate social lives at predominately White universities. This, of course, generates feelings of alienation that often decreases social integration within the school. Similar to Fleming's work, Carter (2001) found that Black students at PWI's have a formidable experience, in which many have feelings of isolation from being one of few African Americans in the school environment; therefore, African American students look for additional Black students for support. This is, then, exacerbated if students attend a larger institution where they are less likely to become involved with campus life and less likely to interact with faculty, campus government, and athletics. As a result, Black males feel isolated and are more likely to exhibit verbal aggressiveness in the classroom (Stikes, 1984); and thus, affects academic motivation.

Mitchell and Dell (1992) conducted a study on racial identity attitudes and participation in campus organizations as a means of social integration on campus. They hypothesized that individuals holding certain racial identities may choose to associate with certain racial groups. The racial identities were described in four stages. The first stage, pre-encounter, is characterized by a belief that Blacks are inferior and White values are preferred; the Encounter stage is characterized by behaviors that are pro-Black; the Immersion-Emerson stage is characterized by an oppositional behavior towards Whites; and the Internalization stage is characterized by adopting sets of values from both Black and Whites groups. As a result of their research, they found that when African American students became more comfortable with their own racial identify (internalization stage), they were more likely to be open to cultural and noncultural events; thus exhibiting a "bicultural" attitude (black students are neutral to race). They found that if students had a pro-White attitude they were less likely to participate in Black oriented activities. 
According to Allen (1992), it was found that students who feel positive about their connections to peers of both races have the greatest level of social involvement. It is interesting to note, however, that Mitchell and Dell (1992) found that African American males had a stronger connection to Black oriented academic and professional organizations than Black females; thus, giving males greater "exposure to Black role models, and support from similar males"(p. 42).

Tinto (1988) asserts that fraternities and sororities, and intramural athletics may also serve to provide individuals with opportunities to establish repetitive contact with other members of the institution and lead to the possibility of integration. In a study conducted by Astin (1975), several factors were identified in the college environment that affected students' persistence in college. His findings showed that students who were involved in social fraternities and sororities or participated in extracurricular activities were less likely to drop out. Additionally, students who participated in intercollegiate sports had a significantly positive effect on persistence. However, the challenge with some predominately White institutions in providing campus affiliated activities for African American students is that, according to Lang (1992), many predominately White campuses have a minimum number of campus-supported activities designed to meet the needs of so many Black and other minority students" (p. 85).

\section{Self- Efficacy}

In addition to institutional supports and social integration, researchers posit that students' self- efficacy plays an integral role in academic motivation and achievement. Self-efficacy is defined as "the belief that one can master situations and control events" (Bandura, 2000). According to Bandura et al. (1996), "unless people believe that they 
can provide desired effects and forestall undesired ones by their actions, they have little incentive to act" (p. 1206).

Perceived self-efficacy is an influential determinant of career choice and development.

The higher the person's perceived efficacy to fulfill educational requirements and occupational roles the wider the career options they seriously consider pursing, the greater the interest they have in them, the better they prepare themselves educationally for different occupational careers, and the greater the staying power in challenging career pursuits. (Lent, Brown, \& Hackett, as cited in Bandura, 2000, p.3)

Therefore, if students possess low self-efficacy, this will affect their motivation and impact their goals and aspirations in college. According to Berry and Asamen (1989), there is an "interrelationship between self efficacy and commitment" (p.233). Students will not make the commitment necessary to achieve in college if they do not perceive themselves as being able to accomplish goals. Black students, for example, have had more

capricious experiences in setting goals and receiving reinforcement for their accomplishment than have Whites at PWI's. Whites are more likely to understand that if they accomplish $A$ they can go to $B$; however, for African American students, this is less clear. (Sedlacek, 1987, p. 489)

A person will commit himself or herself to achieve and pursue only those goals in which he or she is self-efficacious (Berry \& Asamen, 1989). Thus, the stronger the perceived self-efficacy, the higher the goal aspirations one will adopt (Bandura, 1996). As Tinto (1987) asserts, "individual commitments, whether expressed as motivation, 
drive, or effort, prove to be centrally related to departure from institutions of higher education" (p.44). Congruent with this assertion is Lang (1992), who reports that "the more students are comfortable with and believe in themselves, the more social integration will occur; and, when students feel comfortable enough in their abilities to learn and seek help, they are more likely to persist" (p. 39). "Perceived self-efficacy is also one of the most essential student characteristics needed for academic achievement; if students lack the self-efficacy to sustain effort they won't persist" (Berry \& Asamen, 1989, p. 227). Rankin (2003) affirms that

if African American students are to be sufficiently prepared to meet the challenges of the twenty first century, they must come to see themselves as intellectually and effectively competent in both academic and social circles, and know that they are able to graduate from institutions of higher education. (p.76) According to Mayo and Christenfeld (1999), African American students reported lower self-efficacy and internal control of events than did Whites. According to Ogbu (2003), many Black males have a collective efficacy. Collective efficacy or an external locus of control, according to Ogbu (2003), is the belief that one's destiny is determined more by luck, chance, fate or other external forces. Conversely, an internal locus of control suggests that "our thoughts control our actions and that when we realize this executive function of thinking we can positively affect our beliefs, motivation and academic performance" (McCombs, 1991 p.6). And according to Jones (2001), those students who characterize an internal locus of control will influence his or her success (p.11). Since, it is posited that Black males are more likely to have a collective efficacy this, undoubtedly, may contribute to academic beliefs quite different than Black females. For example, as 
reported by Fleming (1984), Black males on White campuses experience feelings of rejection, which makes it difficult for them to muster any intellectual motivation; therefore, Black males have trouble with developing interpersonal relationships. Black females, on the other hand, according to Fleming's research, are adept at domination; however, they feel less likely to use this assertiveness around Black males.. Consequently, Black females develop and use their assertive skills more frequently at PWI's where they are less likely to be in competition with Black males (Fleming, 1984). This characteristic exhibited by Black females, may have implications on their motivation and commitment to succeed at PWI's.

In a study conducted by Hood (1992) on the academic and non-cognitive factors affecting the retention of Black males at PWI's, Black males were more apt to withdraw from the school as a result of academic dismissal. This academic dismissal may be attributable to their self-efficacy beliefs. According to Berry and Asamen (1998), students who are committed and have strong self-efficacy beliefs in the goal of achieving are more likely to do better academically.

\section{Summary}

The literature reviewed has provided great insights into why gender, particularly, gender differences in perceptions of campus climate is one potential reason why there exists a discrepancy in college graduation rates of African American students in higher education. The existing educational attainment gap in graduation rates among African American students can be attributable to the discouraging past that has beset African Americans, the lack of economic opportunities, the susceptibility to academic tracking 
and discipline problems, and crime and imprisonment. In addition to past influences, researchers have also asserted that non-cognitive factors within the institution affect African American students and, possibly, affect the identity and behaviors of Black males differently than females. Students who feel a sense of belonging and feel in sync with the institution are more likely to have positive relationships with faculty and students, thus enhancing their social integration. As a result, students feel better about themselves, thus increasing their self-efficacy and maintaining the motivation to sustain effort to continue their pursuit in higher education. 


\section{Chapter Three}

\section{METHODOLOGY}

To determine if a relationship exists between gender and African American students' perceptions of campus climate, a quantitative research approach was used in this study. This chapter will describe the research design used, the subjects and sampling techniques, the dependent and independent variables, the procedures for data collection and analysis, and concludes with a summary of the study.

\section{Data Collection Method}

I gathered data through two different venues: on campus, and via an on-line survey. Students who identified themselves as undergraduate, African Americans were given a questionnaire to be filled out while the researcher was present. The survey was then distributed on-line by the Dean of students at the university. He sent the introductory letter and the website address where the survey could be accessed by all undergraduate African American students who had an active email account. The survey asked participants to provide responses to a set of demographic factors as well as to three areas of campus climate: (a) institutional supports, (b) social integration, and (c) self-efficacy beliefs. A 5 point Likert scale of: (a) strongly agree, (b) agree, (c) neutral, (d) disagree, and (e) strongly disagree was used to measure students' perceptions of campus climate. In addition, there was one open-ended question that asked students to provide additional information pertaining to institutional and social supports as well as perceptions of selfefficacy.

The total number of surveys answered was 366 with a response rate of $11.5 \%$. The response rate was determined by the total number of surveys distributed on campus 
and via on-line out of the total number of African American undergraduate students with active email accounts. The surveys distributed on campus were returned within 5 minutes while the researcher was present. To minimize duplication of any one survey a note was written on the top of the survey indicating to participants to take the survey only once. Subjects and Sampling

A search for a representative PWI with similar statistics of the nation's graduation rates of African American students was initiated. At the conclusion of the search, the PWI used in this study had a total undergraduate enrollment of 14,417 . Of the undergraduate students enrolled in 2004-fall semester, 15.6\% were African American females, and 7.1\% were African American males. Statistics on the African American students' graduation rates at this institution indicated that the 6-year graduation rate for the 1997 cohort was $29 \%$ and $40 \%$ for Black males and females, respectively.

The target group for the study was all African American part-time and full-time undergraduate students. Students who transferred, dropped out, did not return for the upcoming year or did not have an active email account were not included in the sample. Phases and Time Period of the Study

On September 16-18, 2004 surveys were distributed to undergraduate students on campus, and were returned within 5 minutes of receipt. The same survey was placed on line and sent via email on October 26, 2004 to all African American undergraduate students with an active email account (3187). The data collection was ceased after 10 consecutive days of not receiving responses; data was then terminated on November 27 , 2004. This study utilized data that was collected on campus and on-line. 


\section{Validity and Reliability}

To ensure validity and reliability, I used several methods to create my survey such as reviewing relevant literature, obtaining information through a peer review, and conducting a pilot of the instrument. According to Cohen et al. (2000), pre-testing your questionnaire is crucial to its success. Oppenheim (as cited in Cohen, 2000) states that, "a pilot has several functions, principally to increase the reliability, validity and practicability of the questionnaire" (p. 260). Therefore, I piloted my survey by first distributing the questionnaire to a peer review of 10 teachers to ensure that the questions were clear and asked what I intended to measure. I then arranged a focus group of 10 college students who were representative of the sample of students that I studied; the 10 students who were involved in the pilot of the survey were not part of the final data collection process. The focus group met at a designated time in a designated room. The purpose of the focus group was to give students an opportunity to fill out the survey and to provide feedback pertaining to the questionnaire. At the time of the pilot, I addressed issues related to clarity, appropriateness of each question, length of the survey and noted any additional feedback. The feedback provided me with additional changes and modifications to the survey instrument.

\section{Quantitative Research Design and Data Analysis Methods}

The research design for this study consisted of a series of 40 multiple regression models. The objective was to specify a model that would help quantify and explain relationships between the demographic factors and students' perceptions of campus climate. Respondents' answers to the questions were entered into a statistical software program, SPSS, and analyzed through multiple regression analysis. 


\section{Study Variables}

The independent variables in this study were drawn from existing research and included 20 variables: (a) gender, (b) age, (c) residency status (d) current living arrangement, (e) class designation, (f) college GPA, (g) collegiate sports affiliation (h) marital status (i) number of siblings, (j) father's formal education level, (k) mother's formal education level, (l) parents combined level of income, (m) hours worked per week, (n) work on campus, (o) member of a sorority/fraternity, (p) high school GPA, (q) receiving financial aid, (r) full or part-time student, (s) member of the Black Student Association, and ( $\mathrm{t}$ ) first choice in colleges.

Table 1 describes the independent variables used in the analysis in more detail, and a description of how each variable was coded in SPSS.

The three dependent variables in this study were taken from existing research and consisted of: (a) institutional supports, (b) social integration, and (c) self-efficacy beliefs. Respondents were asked to rate their perceptions of campus climate on the flowing scale: (a) strongly agree, (b) agree (c) neutral, (d) disagree, and (e) strongly disagree. These choices were coded and entered into SPSS as 4,3,2, 1, and 0 respectively. A scale of 4, $3,2,1,0$, were the range of scores for the sum of each index of 0 to 48 ; (The smallest sum was 12 scores of " 0 ", while the highest was 12 scores of " 4 "); To measure as a percentage change, the $0-48$ scale was transformed into a $0-100$ scale by multiplying each score by 2.05 . 
Table 1

Specification of Independent Variables

\begin{tabular}{ll}
\hline Variable & Description and coding \\
\hline 1. Gender & $\begin{array}{l}\text { Gender was coded as a dichotomous variable (Numeric-Ordinal). "Female" } \\
\text { was the reference category. } 0 \text { if female; } 1 \text { male. (Gender is a natural dummy } \\
\text { variable. The compute function is not necessary with variables that have only } \\
\text { two categories). }\end{array}$ \\
& $\begin{array}{l}\text { Number of Years (Numeric-Scale). } \\
\text { 2. Age }\end{array}$ \\
3. Residency status & $\begin{array}{l}\text { "International Student" was the reference category. Since there were three } \\
\text { categories I created two dichotomous variables; one for "out-of-state," and } \\
\text { one for "in-state." }\end{array}$ \\
Housing was coded as a dichotomous variable. (Numeric Ordinal). \\
4. Housing \\
3. Residency
\end{tabular}

7. Sports

Member of a sports team was coded as a dichotomous variable. (NumericOrdinal). "No" was the reference category. (No, the respondent was not a member of a sports team). 0 if no; 1 if yes.

8. Status

Marital status was coded as a dichotomous variable (Numeric- Scale). "Divorced" was the reference category. Since there were three categories of Marital Status, I created two dichotomous variables, one for single, and one for married.

9. Siblings

Number of siblings (Numeric-Scale)

10. Father's education

Father's level of education was coded as a dichotomous variable (NumericScale). "Less than high school graduate" was the reference category. Since there were six categories, I created five dichotomous variables; one for "high school," one for "associate degree," one for "college graduate," one for "master's degree," and one for "doctoral degree."

11. Mother's education

Mother's level of education was coded as a dichotomous variable (NumericScale). "Less than high school" was the reference category. Since there were six categories, I created five dichotomous variables; one for "high school graduate," one for "associate degree," one for "college graduate," one for "master's degree," and one for "doctoral degree." 
Table 1 (continued)

\begin{tabular}{|c|c|}
\hline Variable & Description and coding \\
\hline 12. Income & $\begin{array}{l}\text { Parents combined level of income was coded as a dichotomous variable. } \\
\text { (Numeric-Scale). "Below } 40,000 \text { " was the reference category. Since there } \\
\text { were five categories I created four dichotomous variables; one for " } 40,000- \\
60,000 " \text { one for " } 61,000-80,000 \text {," one for " } 81,000-100,000 \text {," and one for } \\
\text { "above } 100,000 . "\end{array}$ \\
\hline 13. Hours & Hours worked per week (Numeric-Scale). \\
\hline 14. Work & $\begin{array}{l}\text { Work a job on campus was coded as a dichotomous variable (Numeric- } \\
\text { Ordinal). "No" was the reference category. (No, the respondents did not work } \\
\text { a job on campus). } 0 \text { if no; } 1 \text { if yes. }\end{array}$ \\
\hline 15. Member & $\begin{array}{l}\text { A member of a sorority and fraternity was coded as a dichotomous variable } \\
\text { (Numeric-Ordinal). "No" was the reference category. } 0 \text { if no; } 1 \text { if yes. }\end{array}$ \\
\hline 16. H.G.P.A. & $\begin{array}{l}\text { High school G.P.A. was coded as a dichotomous variable (Numeric-Scale). } \\
\text { "Below } 1.99 \text { " was the reference category. Since there were five categories, I } \\
\text { created four dichotomous variable; one for " } 2.0-2.49 \text {," one for " } 2.5-2.99 \text {," one } \\
\text { for " } 3.0-3.5, \text { " and one for "above } 3.5 \text { " }\end{array}$ \\
\hline 17. Financial aid & $\begin{array}{l}\text { Financial aid was coded as a dichotomous variable (Numeric-Ordinal). "No" } \\
\text { was the reference category. (No, the respondents did not receive financial aid). } \\
0 \text { if no; } 1 \text { if yes. }\end{array}$ \\
\hline 18. Status & $\begin{array}{l}\text { Status of the student was coded as a dichotomous variable (Numeric-Ordinal). } \\
\text { "Part-time" was the reference category. } 0 \text { if part-time; } 1 \text { if full-time. }\end{array}$ \\
\hline 19. BSA & $\begin{array}{l}\text { A member of the Black Student Association was coded as a dichotomous } \\
\text { variable (Numeric-Ordinal). "No" was the reference category. } 0 \text { if no; } 1 \text { if yes. }\end{array}$ \\
\hline 20. Choice & $\begin{array}{l}\text { Choice of schools was coded as a dichotomous variable (Numeric- Ordinal). } \\
\text { "No" is the reference category. (No the university was not the respondent's } \\
\text { first choice of schools.) } 0 \text { if no; } 1 \text { if yes }\end{array}$ \\
\hline
\end{tabular}

Table 2 summarizes the specification and coding of the dependent variables. 
Table 2

Specification of Dependent Variables

\begin{tabular}{ll}
\hline Variable & Description \\
\hline 1. Social support & $\begin{array}{l}\text { Answers to each of the twelve questions pertaining to social support were coded } \\
\text { as } 4 \text { if "strongly agree," } 3 \text { if "agree," } 2 \text { if "neutral," } 1 \text { if "disagree," and } 0 \text { if } \\
\text { "strongly disagree" (Numeric-Scale). }\end{array}$ \\
2. Institutional support & $\begin{array}{l}\text { Answers to each of the twelve questions pertaining to institutional support were } \\
\text { coded as } 4 \text { if "strongly agree," } 3 \text { if "agree," } 2 \text { if "neutral," } 1 \text { if "disagree," and } 0 \\
\text { if "strongly disagree" (Numeric-Scale). }\end{array}$ \\
& $\begin{array}{l}\text { Answers to each of the twelve questions pertaining to self-efficacy were coded } \\
\text { as } 4 \text { if "strongly agree," } 3 \text { if "agree," } 2 \text { if "neutral," } 1 \text { if "disagree," and } 0 \text { if } \\
\text { "strongly disagree" (Numeric-Scale). However, a reverse scale of } 0 \text { "strongly } \\
\text { agree," } 1, \text { "agree," } 2, \text { "neutral," } 3, \text { "disagree," } 4, \text { "strongly disagree," was used } \\
\text { for questions stated in the negative. }\end{array}$ \\
\hline
\end{tabular}

Data Analysis

Data analysis was conducted in two stages. In stage one, descriptive statistics were computed to describe the sample and to answer the first research question: What perceptions do African American undergraduate students have about the campus climate? The means, standard deviations and percentages were computed for each variable of each category of campus climate.

The second stage of the analysis focused on hypothesis testing. To answer the second and third research question: To what extent are these perceptions of campus climate a function of gender? To what extent are the perceptions of campus climate a function of other factors? A series of regressions were run on the respondents' ratings on the sum of institutional supports, social integration, and self- efficacy. A regression was run on the total of all three constructs to form one additional index, for a total of 4 different indices. An additional regression model was run for each question within each index (12 questions each). There were a total of 40 regression models. 
A regression model was run for each of the 40 dependent variables. In the first model, social support was run as a function of the 20 demographic factors. In the second model, institutional support was run as a function of demographic factors. In the third model, self-efficacy was run as a function of demographic factors, and in the third model an overall regression model was run with all three constructs. Finally, I ran a regression model for each question within each index.

For each one of the 40 regression models, I used hypothesis testing to determine the significance of their coefficients and the effects of each independent variable on the dependent variable. To determine which variables were significant and should be included in the 40 regression models, variables were removed from each model until only the variables that were significant at the $p=.05$ level were left. The following 12 demographic variables were significant among the three models: (a) father's highest level of education is college, (b) current grade point average 3.5 or higher, (c) current grade point average $3.0-3.5$, (d) current grade point average $2.5-2.99$, (e) age, (f) gender, (g) job on campus, (h) member of the Black Student Association, (I) married, (k) member of a sorority/fraternity, (1) live on campus, and (m) mother's highest level of education is a doctorate. The sum of all three dependent variables was then run as a function of the demographic variables. Variables were removed until only the following six ones remained: (a) member of the Black Student Association, (b) mother's highest level is a doctorate, (c) gender, (d) live on campus, (e) current grade point average is 3.0-3.5, (f) and a current grade point average above 3.5. These 12 significant variables became the independent variables that were run in the 40 regression models. 


\section{Conclusion}

The purpose for using quantitative research was to ascertain the affect of gender on African American students' perceptions of campus climate pertaining to institutional supports, social integration and academic aspirations or self-efficacy. Data were gathered from a sample of undergraduate African American students at a 4-year public PWI. I used a questionnaire to elicit responses of students' perceptions by randomly distributing surveys to Black male and female undergraduate students on the campus and via email. To ensure validity and reliability of the questionnaire, I reviewed relevant literature, obtained information through a peer review, and conducted a pilot of the survey. The independent variables used in the study were (a) gender, (b) age, (c) residency status, (d) current living arrangement, (e) class designation, (f) college G.P.A., (g) member of a collegiate sports team, (h) marital status, (i) number of siblings, (j) father's formal education level, (k) mother's formal level of education, (l) parents combined level of income, (m) hours worked per week, (n) work on campus (o) member of a sorority or fraternity, (p) high school G.P.A., (q) financial aid recipient, (r) part-time or full-time student, (s) member of the Black Student Association, and ( $\mathrm{t}$ ) first choice of schools. The significant independent variables used in the 40 models were (a).gender, (b).live on campus, (c). job on campus (d).mother's highest level of education is a doctorate, (e). father's highest level of education is college, (f).member of sorority/fraternity, (g).member of the BSA, (h).age, (i).class status, (j).financial aid, (k).current grade point average 2.5-2.99, and (1).current grade point average 3.0-3.5. The dependent variables were used to measure students' perceptions of campus climate. The dependent variables were: (1) social supports, (2) institutional supports, and (3) self- efficacy. The data 
collected were statistically tested to determine if a relationship exists between the dependent and independent variables; thus answering the research questions posed. 


\section{Chapter Four}

\section{FINDINGS}

In this chapter, the results of the investigation on the effects of African American students' perceptions of campus climate will be discussed. The chapter will consist of four sections: (1) sampling and survey procedures; (2) characteristics of the sample; (3) sample demographics including sample means and standard deviations and; (4) the results of the analysis used to address the study's research questions. In addition, I will identify significant individual variables in the models as well as the $\mathrm{R}^{2}$ for the final models. I will also discuss the respondents' qualitative data to substantiate findings and provide additional insights to students' perceptions of campus climate.

\section{Sample and Survey Procedures}

The study focused on the demographic factors of the respondents as well as their perceptions of social and institutional supports, and self-efficacy. The subjects consisted of 3,187 undergraduate African American students who had active email accounts with the university. The results of the survey yielded 357 questionnaires that were answered within 4 weeks of the survey placed on line. In addition to the online surveys, 57 questionnaires were distributed to students on campus during a period of 3 days for a total response of 414 . However, 48 of these questionnaires were incomplete, and were not used in the final analysis ${ }^{1}$. Ultimately, a total of 366 surveys were used in the study for a response rate of $11.5 \%$.

One potential limitation in using e-mail accounts for distribution of my survey was that not all African American students had active e-mail accounts. However, since

\footnotetext{
${ }^{1}$ A survey was determined incomplete if it was missing a considerable number of responses, decreasing the significance of the survey. Surveys missing more than half of the responses were not used in the analysis.
} 
only 83 out of the 3270 African American students at the university were in this situation $(2.5 \%)$, the assumption was made that any potential bias arising from not having an active e-mail account would be minimal and as such, would not significantly distort the results of my study.

\section{Characteristics of the Sample}

In general, the majority of the respondents were female, single, and enrolled as full-time, in- state students. The average age of the respondents was 23.4 , and they were most likely to be seniors, did not work on campus and were not a member of a sports team. The majority of students held a grade point average between 2.5 and 2.99 , and were not a member of a campus sorority or the Black Student Association. The typical respondents had an average of slightly more than two siblings; their father and mothers' highest level of education was high school; their parents' combined income level was $40,000-60,000$, and the majority of the respondents received financial aid. In addition, most of the respondents held a high school grade point average between a 3.0 and 3.5 , and this university was not their first choice of schools to attend.

As the findings demonstrate, a disproportionate number of females participated in this study, given their respective proportions in the school population. For example, the population of African American undergraduate students at the university consisted of $31.1 \%$ Black males and $68.8 \%$ Black females; however the sample population consisted of $23.8 \%$ Black males and $76.2 \%$ Black females. Tables 3 and 4 represent the sample distribution in terms of frequencies, percentiles and the mean and standard deviations. 


\section{Research Question \#1}

As previously mentioned, there were three research questions that guided this study. The following section will provide findings to the first research question: What are African American students' perceptions of campus climate? The subsequent tables provide the sample means and standard deviations of perceptions for each area of campus climate for both African American males and females. Respondents were asked to rate their perceptions of social supports and institutional supports at the university as well as their self-efficacy on a scale from 0 to 4 , where a "4" means strongly agree, a "3" means agree, a "2" means neutral, a "1" means disagree, and a " 0 " means strongly disagree. However, because two of the statements regarding self-efficacy were phrased in the negative, (1)“I usually compare my academic success to others"(question \#12), and (2) "I look to others for help before beginning a challenging task"(question \#6), the scoring scale was reversed for these questions so that the lower score represented more selfefficacious behavior. Table 5 presents the means and standard deviations for the 12 statements that make up the dependent variable, social supports.

As indicated in Table 5, the highest mean among the perceptions of social supports for males was, "I feel comfortable with peers of other races", while the lowest mean was," Most of my high school friends attend this university". The highest mean among the perceptions of social supports for females was also, "I feel comfortable with peers of others races", and the lowest mean was their involvement with the student union at the university. The total average score for males was 2.28 , and for females was 2.07 , and the difference between the mean was statistically significant at the $p=.01$ level. Considering that the university is a predominately White institution, the fact that both 
Table 3

Demographic Characteristics of the Sample

\begin{tabular}{|c|c|c|c|c|c|}
\hline Characteristic & Category & Number & Percent & Mean & S.D \\
\hline \multirow[t]{3}{*}{ Gender } & Male & 87 & 23.8 & & \\
\hline & Female & 326 & 76.2 & & \\
\hline & Total & 366 & 100 & & \\
\hline \multirow[t]{4}{*}{ Marital status } & Single & 320 & 87.4 & & \\
\hline & Married & 35 & 9.6 & & \\
\hline & Divorced & 11 & 3 & & \\
\hline & Total & 366 & 100 & & \\
\hline \multirow[t]{5}{*}{ Current age } & $18-28.9$ & 317 & 86.6 & & \\
\hline & $29-39.9$ & 32 & 8.74 & & \\
\hline & $40-50.9$ & 12 & 3.3 & & \\
\hline & $51-61.9$ & 5 & 1.36 & & \\
\hline & Total & 366 & 100 & 23.04 & 6.94 \\
\hline \multirow[t]{5}{*}{ Number of siblings } & $0-3$ & 304 & 83 & & \\
\hline & $4-7$ & 52 & 14.2 & & \\
\hline & $8-11$ & 7 & 2 & & \\
\hline & $12-15$ & 3 & .8 & & \\
\hline & Total & 366 & 100 & 2.27 & 2.16 \\
\hline \multirow[t]{6}{*}{ Parent's combined level of income } & Below 40,000 & 102 & 27.9 & & \\
\hline & $40,000-60,000$ & 118 & 32.2 & & \\
\hline & $61,000-80,000$ & 82 & 22.4 & & \\
\hline & $81,000-100,000$ & 40 & 10.9 & & \\
\hline & Above 100,000 & 24 & 6.6 & & \\
\hline & Total & 366 & 100 & & \\
\hline \multirow[t]{7}{*}{ Father's level of education } & $<$ than high school & 39 & 10.7 & & \\
\hline & High School & 187 & 51.1 & & \\
\hline & Associate Degree & 8 & 15.8 & & \\
\hline & College Degree & 54 & 14.8 & & \\
\hline & Master's Degree & 2 & 6 & & \\
\hline & Doctoral Degree & 6 & 1.6 & & \\
\hline & Total & 366 & 100 & & \\
\hline \multirow[t]{7}{*}{ Mother's level of education } & $<$ than high school & 27 & 7.33 & & \\
\hline & High School & 151 & 41.3 & & \\
\hline & Associate Degree & 88 & 24 & & \\
\hline & College Degree & 69 & 18.9 & & \\
\hline & Master's Degree & 30 & 8.2 & & \\
\hline & Doctoral Degree & 1 & .27 & & \\
\hline & Total & 366 & 100 & & \\
\hline \multirow[t]{3}{*}{ Registration status } & Full-time & 326 & 89.1 & & \\
\hline & Part-time & 40 & 10.9 & & \\
\hline & Total & 366 & 100 & & \\
\hline
\end{tabular}


Table 3 (continued)

\begin{tabular}{|c|c|c|c|c|c|}
\hline Characteristic & Category & Number & Percent & Mean & S.D \\
\hline Housing status & $\begin{array}{l}\text { Off Campus } \\
\text { On Campus } \\
\text { Total }\end{array}$ & $\begin{array}{l}136 \\
230 \\
366\end{array}$ & $\begin{array}{l}37.2 \\
62.8 \\
100\end{array}$ & & \\
\hline Residency status & $\begin{array}{l}\text { In-State } \\
\text { Out-of-state } \\
\text { International } \\
\text { Total }\end{array}$ & $\begin{array}{c}342 \\
20 \\
4 \\
366\end{array}$ & $\begin{array}{c}93.4 \\
5.5 \\
1.1 \\
100\end{array}$ & & \\
\hline Class designation & $\begin{array}{l}\text { Freshman } \\
\text { Sophomore } \\
\text { Junior } \\
\text { Senior } \\
\text { Total }\end{array}$ & \begin{tabular}{c|}
41 \\
98 \\
113 \\
114 \\
366
\end{tabular} & $\begin{array}{l}11.2 \\
26.8 \\
30.9 \\
31.1 \\
100\end{array}$ & & \\
\hline Hours worked on campus & $\begin{array}{l}0-10.9 \\
11-21.9 \\
22-32.9 \\
33-43.9 \\
\text { Total }\end{array}$ & $\begin{array}{c}299 \\
51 \\
10 \\
6 \\
366\end{array}$ & $\begin{array}{c}81.6 \\
14 \\
2.7 \\
1.7 \\
100\end{array}$ & 4.33 & 8.38 \\
\hline Work on campus & $\begin{array}{l}\text { Yes } \\
\text { No } \\
\text { Total }\end{array}$ & $\begin{array}{c}97 \\
269 \\
366\end{array}$ & $\begin{array}{l}26.5 \\
73.5 \\
100\end{array}$ & & \\
\hline Financial aid & $\begin{array}{l}\text { Yes } \\
\text { No } \\
\text { Total }\end{array}$ & $\begin{array}{c}327 \\
39 \\
366\end{array}$ & $\begin{array}{l}89.3 \\
10.7 \\
100\end{array}$ & & \\
\hline First choice of schools & $\begin{array}{l}\text { Yes } \\
\text { No } \\
\text { Total }\end{array}$ & $\begin{array}{l}160 \\
206 \\
366\end{array}$ & $\begin{array}{l}43.7 \\
56.3 \\
100\end{array}$ & & \\
\hline Member of fraternity/sorority & $\begin{array}{l}\text { Yes } \\
\text { No } \\
\text { Total }\end{array}$ & $\begin{array}{c}18 \\
348 \\
366\end{array}$ & $\begin{array}{c}4.9 \\
95.1 \\
100\end{array}$ & & \\
\hline Member of black student association & $\begin{array}{l}\text { Yes } \\
\text { No } \\
\text { Total }\end{array}$ & $\begin{array}{c}31 \\
335 \\
366\end{array}$ & $\begin{array}{c}8.5 \\
91.5 \\
100\end{array}$ & & \\
\hline Member of a collegiate sports team & $\begin{array}{l}\text { Yes } \\
\text { No } \\
\text { Total }\end{array}$ & $\begin{array}{c}7 \\
359 \\
366\end{array}$ & $\begin{array}{c}1.9 \\
98.1 \\
100\end{array}$ & & \\
\hline
\end{tabular}

male and female perceptions were highest for the comfort they felt with peers of other races is an important finding that possibly suggests positive social integration within the university. 
Table 4

Academic Characteristics of the Sample

\begin{tabular}{lccc}
\hline Characteristic & Category & Number & Percent \\
\hline High school G.P.A. & Below 1.99 & 26 & 1.4 \\
& $2.0-2.49$ & 21 & 5.7 \\
& $2.5-2.99$ & 87 & 23.8 \\
& $3.0-3.5$ & 163 & 44.5 \\
& Above 3.5 & 90 & 24.6 \\
& Total & 366 & 100 \\
College G.P.A. & & 14 & 3.8 \\
& Below 1.99 & 72 & 19.7 \\
& $2.0-2.49$ & 133 & 36.3 \\
& $2.5-2.99$ & 123 & 33.6 \\
& $3.0-3.5$ & 24 & 6.6 \\
& Above 3.5 & 366 & 100 \\
\hline
\end{tabular}

In terms of the statements that make up the study's second dependent variable, institutional supports, Table 6 provides the dependent variables for institutional supports. Examination of Table 6 shows that for institutional supports, the highest mean for males was, "The faculty is fair to all students regardless of their racial background", while the lowest mean was, "My college advisor is available when I need him/her". The highest mean for females were, "I would seek help from tutoring services offered at the school if I needed it", while the lowest mean was, "My college advisor has met with me to go over my academic progress". The total average score for institutional support for males was 2.86 versus 2.78 for females; however this difference was not statistically significant. An interesting finding is that both males and females scored lowest on the variables related to the availability of their college advisors. Considering the support that is provided by university advisors, the negative perceptions held by students of both genders has potentially serious implications for students' academic success at this institution. 
Table 5

Sample Means and Standard Deviations for the Twelve Statements for Social Support Variable

\begin{tabular}{|c|c|c|c|c|}
\hline \multirow[t]{2}{*}{ Social Support Statements } & \multicolumn{2}{|c|}{ Male } & \multicolumn{2}{|c|}{ Female } \\
\hline & Mean & SD & Mean & SD \\
\hline $\begin{array}{l}\text { 1. Majority of my high school friends were African } \\
\text { American }\end{array}$ & 2.09 & 1.36 & 2.06 & 1.33 \\
\hline 2. Majority of my high school friends attend college & 2.47 & 1.30 & 2.55 & 1.23 \\
\hline 3. My peer group at this college is African American & 2.68 & 1.04 & 2.70 & 1.10 \\
\hline 4. Most of my high school friends attend this college & 1.05 & 1.15 & .88 & .99 \\
\hline 5. I feel comfortable with peers of other races & 3.36 & .79 & 3.45 & .67 \\
\hline 6. I am involved with intramural sports at college & 1.48 & 1.43 & .54 & .78 \\
\hline $\begin{array}{l}\text { 7. I am involved with the student union here at this } \\
\text { college }\end{array}$ & 1.11 & 1.12 & .84 & .99 \\
\hline 8. I am involved with extracurricular activities & 2.32 & 1.50 & 2.16 & 1.43 \\
\hline 9. I often participate in social gatherings at college & 2.35 & 1.24 & 2.11 & 1.27 \\
\hline 10. It has been easy to make friends with others here & 3.11 & .93 & 2.74 & .93 \\
\hline $\begin{array}{l}\text { 11. Most of the students here have values the same as } \\
\text { my own }\end{array}$ & 2.57 & .92 & 2.35 & .87 \\
\hline 12. I am satisfied with my social life here & 2.82 & 1.00 & 2.55 & .94 \\
\hline Average of social support & 2.28 & & 2.07 & \\
\hline
\end{tabular}

In addition to the proceeding dependent variables, Table 7 illustrates the means and standards deviations of the 12 statements that make up the dependent variable, selfefficacy. As shown in this table, the highest mean for males was "Education is very important to me", while the lowest mean was, "I feel good about my current G.P.A". The highest mean for females was also, "Education is very important to me", while the lowest mean was, "I feel good about my current G.P.A". The total average score for students" perceptions of self-efficacy for both males and females was 2.94. It is interesting to note 
Table 6

Sample Means and Standard Deviations for the Twelve Statements for Institutional

Support

\begin{tabular}{|c|c|c|c|c|}
\hline \multirow[t]{2}{*}{ Institutional support statements } & \multicolumn{2}{|c|}{ Male } & \multicolumn{2}{|c|}{ Female } \\
\hline & Mean & SD & Mean & SD \\
\hline 1. My college advisor is available when I need him/her & 2.56 & .96 & 2.56 & .98 \\
\hline $\begin{array}{l}\text { 2. My college advisor has met with me to go over my } \\
\text { academic progress }\end{array}$ & 2.59 & 1.05 & 2.53 & 1.15 \\
\hline $\begin{array}{l}\text { 3. The university has provided me with counseling resources } \\
\text { if I need them }\end{array}$ & 2.91 & .67 & 2.90 & .84 \\
\hline $\begin{array}{l}\text { 4. The university has provided me with mentoring resources } \\
\text { if I need them }\end{array}$ & 2.80 & .78 & 2.70 & .92 \\
\hline $\begin{array}{l}\text { 5. I feel supported by the academic services offered by the } \\
\text { university }\end{array}$ & 2.83 & .80 & 2.69 & .96 \\
\hline $\begin{array}{l}\text { 6. The financial aid office has been supportive in meeting my } \\
\text { financial needs }\end{array}$ & 2.74 & 1.06 & 2.54 & 1.18 \\
\hline 7. The faculty is approachable outside of the classroom & 3.03 & .67 & 2.94 & .78 \\
\hline $\begin{array}{l}8 \text {. The faculty is fair to all students regardless of their racial } \\
\text { background }\end{array}$ & 3.15 & .71 & 2.93 & .84 \\
\hline $\begin{array}{l}\text { 9. I would seek help from tutoring services offered at the } \\
\text { school if I needed it }\end{array}$ & 3.00 & .86 & 3.17 & .70 \\
\hline $\begin{array}{l}\text { 10. Academic advisors/counselors are concerned with my } \\
\text { academic performance }\end{array}$ & 2.74 & .80 & 2.54 & .87 \\
\hline 11. My professors listen to my comments/questions & 3.03 & .72 & 3.00 & 68 \\
\hline 12. My professors encourage me to do my best & 3.01 & .88 & 2.91 & .75 \\
\hline Average of institutional support & 2.86 & & 2.78 & \\
\hline
\end{tabular}

that the percentage of females who had a GPA below a 1.99 was less than males; $3.6 \%$ versus $4.7 \%$; however, on average, males seemed to feel better about their current GPA than females. 
Table 7

Sample Means and Standard Deviations for the Twelve Statements for Self-Efficacy

\begin{tabular}{lcccc}
\hline Self-efficacy statements & \multicolumn{3}{c}{ Male } & \multicolumn{2}{c}{ Female } \\
\cline { 2 - 5 } & Mean & SD & Mean & SD \\
\hline 1. I feel successful at the university & 3.56 & .54 & 3.35 & .66 \\
2. I feel good about my current G.P.A & 2.45 & 1.19 & 2.19 & 1.13 \\
3. I take on challenges in my courses & 3.11 & .68 & 2.98 & .67 \\
4. I feel that I can graduate from college in four years & 2.47 & 1.23 & 2.51 & 1.34 \\
5. I feel I can meet all academic goals given by my & 3.08 & .75 & 2.91 & .76 \\
professors & & & & \\
6. I usually compare my academic success to others & 1.54 & 1.12 & 1.82 & 1.16 \\
7. I am committed to graduating from this university & 3.62 & .57 & 3.58 & .76 \\
8. I have plans to pursue graduate school & 2.78 & 1.07 & 3.15 & 1.01 \\
9. I am motivated to do well in school & 3.32 & .73 & 3.40 & .77 \\
10. Education is very important to me & .70 & .59 & 3.79 & .44 \\
11. I have control over my future & 3.43 & .78 & 3.47 & .71 \\
$\begin{array}{l}\text { 12. I look to others for help before beginning a } \\
\text { challenging task }\end{array}$ & 2.22 & .92 & 2.20 & 1.03 \\
\hline \begin{tabular}{l} 
Average of self-efficacy \\
\hline
\end{tabular} & $\mathbf{2 . 9 4}$ & & $\mathbf{2 . 9 4}$ & \\
\hline
\end{tabular}

Effects of the Independent Variables on the Dependent Variables

The following section will address the results of the regressions used to answer research questions two and three. These research questions address the importance of gender and other demographic factors as a means of explaining differences in perceptions of campus climate. Given that the answers to the research questions come from the same set of regression models, the effects of gender will be explored together with the effects of other demographic variables. Throughout the analysis, the $p=.05$ level of significance will be used to minimize the probability of a Type 1 error. 
This section begins by presenting the regression models by construct (social supports, institutional supports, and self-efficacy), starting with the significant variables for the entire construct, and is then is followed by the results from select regressions involving the individual questions themselves. In selecting which individual regressions to report only those regressions with an $\mathrm{R}^{2}$ of $10 \%$ or greater will be discussed in the text. Significant Demographic Variables

There were several demographic variables that were significant in this study. This information can be found in Tables $8,16,18$, and 20 , where the results of the four regression models that explain the variation in student scores of campus climate: social supports, institutional supports, self-efficacy, and the sum of the previous three measures are reported. In these models, the constructs were regressed on a series of demographic variables, many of them modeled as dummy variables, with the omitted reference category presented in the tables. Moreover, since the dependent variables were measured on a 1-100 scale, the estimated coefficients represent percentage change.

\section{Social Supports}

The results of the final regression model for social supports are presented in Table 8 and shows that seven independent variables were significant determinants of social support. These variables included, age; gender; job on campus; living on campus; married; and a member of a sorority/fraternity and Black Student Association. With the exception of "age", all variables had positive coefficients. The overall regression explained $24 \%$ of the variation in students' perceptions of social supports on campus. 
Table 8

Significant Independent Variables for Social Supports

\begin{tabular}{lccc}
\hline Independent variables & Reference category & Est. coefficient & T-stat \\
\hline Age & & $.24^{* *}$ & -6.22 \\
Gender & Female & $2.09^{* *}$ & 3.21 \\
Job on campus & No & $2.75^{* *}$ & 4.44 \\
Member of the Black Student Association & No & $3.93^{* *}$ & 3.97 \\
Married & Divorced & $-5.42^{* *}$ & -5.95 \\
Member of sorority and/or fraternity & No & $3.28^{*}$ & 2.55 \\
Live on campus & No & $2.85^{* *}$ & 5.09 \\
\hline
\end{tabular}

${ }^{*} \mathrm{p}<.05 ;{ }^{* *} \mathrm{p}<.001$

The above results suggest that students who are married are $5.5 \%$ less likely than divorced students to be socially integrated within the university while males are $2 \%$ more likely than females to feel socially integrated at school. With this said, it is important to make social events more available for married students. Given that visibility facilitates a student's social integration within the university; it is, then, understandable that the findings that indicate living on campus, having a job on campus, being a member of a sorority/fraternity, or the Black Student Association would increase one's feelings of social support at college. It is also interesting to note that the student's age influences their perceptions of social integration; particularly, younger students feel more socially integrated.

Regression Models for the 12 Dependent Variables for Social Supports

Given the interesting findings regarding social support for African American students on campus, a more detailed analysis was conducted on the individual statements 
that comprised the social support index. Specifically, regressions were run for each of the 12 statements, covering such topics as students' peer group (high school and college friends), involvement in social gatherings, and the student's overall satisfaction with their social life at the university. The results of those regressions with an $\mathrm{R}^{2}$ of $10 \%$ or greater are reported in Tables 9 through 15.

Table 9

Significant Independent Variables for the Dependent Variable, The Majority of My High

School Friends Are African American $\left(R^{2}=10.8 \%\right)$

\begin{tabular}{lcc}
\hline Independent variable & Est. coefficient & T-Stat \\
\hline High school GPA above 3.5 & $.63^{* *}$ & 4.00 \\
Parent's combined income between 80,000-100,000 & $-.76^{* *}$ & -3.41 \\
Mother's highest level of education is college & $-.55^{* *}$ & -3.13 \\
\hline$* * \mathrm{p}<.001$ & &
\end{tabular}

Table 10

Significant Independent Variables for the Dependent Variable, The Majority of My Peers at The University Are African American $\left(R^{2}=16.5 \%\right)$

\begin{tabular}{lcc}
\hline Independent Variable & Est. Coefficient & T-Stat \\
\hline Age & $-.06^{* *}$ & -8.18 \\
\hline
\end{tabular}

$* * \mathrm{p}<.001$ 
Table 11

Significant Independent Variables for the Dependent Variable, The Majority of My High

School Friends Attend This University $\left(R^{2}=11.2 \%\right)$

\begin{tabular}{lcc}
\hline Independent variable & Est. coefficient & T-Stat \\
\hline Single & $.61^{* *}$ & 3.80 \\
$\begin{array}{l}\text { Mother's highest level of education is an associate } \\
\text { degree }\end{array}$ & $.37^{* *}$ & 2.95 \\
High school G.P.A. between 2.5-2.99 & $-.44^{* *}$ & -3.54 \\
Senior status & $-.41^{* *}$ & -3.58 \\
\hline
\end{tabular}

$* * \mathrm{p}<.001$

Table 12

Significant Independent Variables for the Dependent Variable, I Am Involved with the

Student Union Here at This College $\left(R^{2}=14 \%\right)$

\begin{tabular}{lcc}
\hline Independent variable & Est. coefficient & T-Stat \\
\hline BSA & $.76^{* *}$ & 4.02 \\
Job on campus & $.47^{* *}$ & 3.90 \\
Sorority/fraternity & $.68^{* *}$ & 2.73 \\
Gender & $.27^{*}$ & 2.10 \\
Live on campus & $.34^{* *}$ & 3.05 \\
\hline
\end{tabular}

$* \mathrm{p}<.05 ; * * \mathrm{p}<.001$

As shown in Tables 9 through 15, there were seven regressions that surpassed the $\mathrm{R}^{2}=.10$ threshold; the range for these regressions was $11 \%$ to $24 \%$ with highest $\mathrm{R}^{2}$ reserved for the statement, "I often participate in social gatherings at this university". The coefficients among the significant independent variables for the 
Table 13

Significant Independent Variables for the Dependent Variable, I am Involved With

Intramural Sports $\left(R^{2}=22 \%\right)$

\begin{tabular}{lcc}
\hline Independent variable & Est. coefficient & T-Stat \\
\hline Gender & $.94^{* *}$ & 7.80 \\
Live on campus & $.30^{* *}$ & 2.53 \\
$\begin{array}{l}\text { Father's highest level of education is a } \\
\text { doctorate }\end{array}$ & $2.00^{* *}$ & 4.55 \\
Fathers highest level of education is college & $.45^{* *}$ & 2.74 \\
\hline
\end{tabular}

$* * \mathrm{p}<.001$

Table 14

Significant Independent Variables for Dependent Variable, I Am Involved With

Extracurricular Activities $\left(R^{2}=12.8 \%\right)$

\begin{tabular}{lcc}
\hline Independent variable & Est. coefficient & T-Stat \\
\hline Job on campus & $.70^{* *}$ & 4.09 \\
BSA & $.80^{* *}$ & 3.00 \\
Sorority/fraternity & $.95^{* *}$ & 2.74 \\
Married & $-.83^{* *}$ & -3.24 \\
\hline
\end{tabular}

$* * \mathrm{p}<.001$

regressions ranged from -1.42 to 2.00 , with the largest coefficient for "Fathers doctorate" for the statement, "I am involved in intramural sports at the university".

Interesting findings emerged in regards to the students' perceptions of their peer group at both high school and the university. The findings indicate that students whose high school GPA was above 3.5 were more likely to have majority African American 
Table 15

Significant Independent Variables for the Dependent Variable, I Am Involved With Social Gatherings $\left(R^{2}=24.2 \%\right)$

\begin{tabular}{lcc}
\hline Independent variable & Est. coefficient & T-Stat \\
\hline Married & $-1.42^{* *}$ & -6.64 \\
Live on campus & $.77^{* *}$ & 5.81 \\
BSA & $1.00^{* *}$ & 4.01 \\
Sorority/fraternity & $.70^{*}$ & 2.28 \\
Job on campus & $.55^{* *}$ & 3.72 \\
Mother's highest level of education is college & $.50^{* *}$ & 3.00 \\
\hline
\end{tabular}

$* \mathrm{p}<.05 ; * * \mathrm{p}<.001$

peers in high school than students with a high school GPA below a 1.99. Students who are single were more likely to have high school friends attend the university than students who are divorced; and seniors were less likely to have their high school friends attend the university than freshmen. Additionally, students who had a majority of African American peers at the university were more likely to be younger students.

In relation to parents' education and income level, a student whose mother has a college degree was less likely to have majority African American high school friends than a student whose mother has less than a high school diploma. Students whose mother's highest level of education is an associate degree were more likely to have high school friends attend the university than students whose mother has less than a high school diploma.

A surprising finding developed with students' involvement in intramural sports. According to the findings, students whose fathers' highest level of education is a doctoral 
degree were approximately $2 \%$ more likely to be involved with intramural sports than students whose father has less than a high school diploma. Additionally, males and students who live on campus were more likely to be involved in intramural sports. This is no surprise considering that living on campus provides better proximity and opportunity to become involved with campus related sports.

Students who are married are less likely to be involved with social gatherings and extracurricular activities at the university. Also, students who are members of a sorority/fraternity and the Black Student Association, and live on campus were more likely to be involved with social gatherings and the student union. A surprising finding is that a student whose mother's highest level of education is a college degree was more likely than students whose mother has less than a high school diploma to be involved with social gatherings. This, perhaps, is a result of the many resources available to college-educated parents and their exposure to college related social events. Also, similar to the overall social support construct, students who are members of the Black Student Association, sorority/fraternity, or have a job on campus were more likely to be involved in extracurricular activities than those students who were not. Given the nature of sororities and fraternities, it is no surprise that students who were involved with campus groups were more involved in other activities at the school.

\section{Institutional Supports}

The results of the final regression model for institutional supports are presented in Table 16 and shows that only one independent variable was significant, "Fathers College". Table 16 describes the variable. 
Table 16

Significant Independent Variables for Institutional Support

\begin{tabular}{llll}
\hline Independent variable & Reference category & Est. coefficient & T-Stat \\
\hline Father's college & Less than high school & $-1.91^{*}$ & -2.09 \\
\hline & & & \\
$* \mathrm{p}<.05$ & & &
\end{tabular}

Although the overall index regression yielded only one significant variable, and had an unacceptable low $\mathrm{R}^{2}$ of just $1 \%$, individual regressions were run with each question in the index that did produce some interesting findings.

Individual Regressions for the 12 Dependent Variables for Institutional Supports

The institutional supports construct was comprised of questions pertaining to college resources, such as academic advisors, counseling, mentoring, and perceptions of the faculty. Similar to the statements that made up the social support index, I ran regressions on each of the 12 individual statements that formed the institutional support index. However only one regression yielded an $\mathrm{R}^{2}$ of at least $10 \%$ and it was for the statement, "The financial aid office has been supportive in meeting my financial needs". The significant independent variables and their regressions are reported in Table 17.

Examination of Table 17 shows that there were three significant variables in this regression, with their estimated coefficients ranging from -.02 to .92 . The largest coefficient was for students who receive financial aid; this is not surprising since students who receive financial aid at the university are more likely to feel supported by the financial aid office than those who do not receive financial aid. Additionally, in-state students were slightly more likely than international students to feel supported by the financial aid office. This finding is troubling in that students who live internationally 
Table 17

Significant Independent Variables for the Dependent Variable, The Financial Aid Office Has Been Supportive In Meeting My Financial Needs $\left(R^{2}=10 \%\right)$

\begin{tabular}{lcc}
\hline Independent variable & Est. coefficient & T-Stat \\
\hline Financial aid & $.92^{* *}$ & 4.81 \\
Age & $-.02^{*}$ & 2.31 \\
In-state & $.63^{*}$ & -2.53 \\
\hline
\end{tabular}

${ }^{*} \mathrm{p}<.05 ; * * \mathrm{p}<.001$

may have higher tuition levels and would most likely benefit from financial assistance. Additionally, age had a slight influence on students' perceptions of the financial aid office; older students were less likely to feel supported than younger students.

Self-Efficacy

The results of the final regression model for self-efficacy yielded 3 significant variables, all pertaining to a student's college grade point average. The coefficients for the three significant variables ranged from -1.41 to 5.04 , where the highest coefficient was for "College GPA above 3.5". The overall regression model explained $16 \%$ of the variation in students' self-efficacy. Table 18 presents the estimated coefficients, and tstatistic for these three variables.

As indicated in Table 18, it is apparent that the higher one's current college GPA is (between 3.0 and above 3.5) the more self-efficacious they feel. This, of course, is understandable given that positive academic performance helps students believe in themselves, and, thus, contributes to increase motivation and commitment to achieve. However, a more counterintuitive finding was that if students had a current GPA between 
Table 18

Significant Independent Variables for Self-Efficacy

\begin{tabular}{lccc}
\hline Independent variable & Reference category & Est. coefficient & T-Stat \\
\hline College GPA above 3.5 & Below 1.99 & $5.04^{* *}$ & 4.84 \\
College GPA between 3.0-3.5 & Below 1.99 & $2.65^{* *}$ & 4.87 \\
College GPA between 2.5-2.99 & Below 1.99 & $-1.41^{*}$ & -2.57 \\
\hline
\end{tabular}

${ }^{*} \mathrm{p}<.05 ; * \mathrm{p}<.001$

a 2.5 and 2.99 they were less likely to feel self-efficacious than students whose current GPA was below a 1.99 .

Regression Models for the 12 Dependent Variables for Self-Efficacy

As was shown in Table 18 students' college GPA was the only significant variable for self-efficacy, indicating that a student's current GPA correlates with his or her perceptions of self-efficacy. As a result of the findings in the overall construct for self-efficacy, additional regressions were run to determine if there exists other factors, particularly non-academic indicators that correlate with perceptions of self-efficacy.

Given the interesting findings regarding the self-efficacy of African American students, a more detailed analysis was conducted on the individual statements that comprised the index for self-efficacy. The self-efficacy construct asked questions pertaining to the students' ability to control their success at school, to graduate, to manage challenges and to establish and accomplish goals. The coefficients among the 10 individual regressions ranged from -1.00 to 1.40 . The largest coefficient was for the independent variable, "College GPA above 3.5".

Table 19 illustrates the results of the two significant regressions that exceeded the $\mathrm{R}^{2}$ of $10 \%$; and presents the estimated coefficients, t-statistic, and levels of significance. 
Table 19

Significant Independent Variables For The Dependent Variable, I Feel Good About My

Current College Grade Point Average $\left(R^{2}=41.5 \%\right)$

\begin{tabular}{lcc}
\hline Independent variable & Est. coefficient & T-Stat \\
\hline College GPA above 3.5 & $1.40^{* *}$ & 5.90 \\
College GPA between 3.0-3.5 & $1.01^{* *}$ & 8.68 \\
College GPA between 2.5-2.99 & $-.44^{* *}$ & -3.51 \\
College GPA between 2.0-2.49 & $-1.00^{* *}$ & -6.91 \\
Age & $.028^{* *}$ & 3.21 \\
\hline$* * \mathrm{p}<.001$ & & \\
\hline
\end{tabular}

Table 20

Significant Independent Variables for The Dependent Variable, I Can Graduate From College In Four Years $\left(R^{2}=16.1 \%\right)$

\begin{tabular}{lcc}
\hline Independent variable & Est. coefficient & T-Stat \\
\hline Married & $.52^{*}$ & 2.21 \\
College GPA between $2.0-2.49$ & $-.73^{* *}$ & -4.33 \\
Senior status & $-.61^{* *}$ & -4.20 \\
Parents combined income of 40,000-60,000 & $-.32^{*}$ & -2.19 \\
BSA & $.51^{*}$ & 2.05 \\
\hline
\end{tabular}

${ }^{*} \mathrm{p}<.05 ; * * \mathrm{p}<.001$

As a result of these individual regressions, several other factors emerged regarding students' perceptions of self-efficacy. For example, the student's age was a 
significant determinant of how they felt about their academic status; in particular, as age increased students felt more self-efficacious.

With regards to students' perceptions of their ability to graduate in four years, married students were more likely than single students to feel they can graduate in four years; and seniors were less likely to feel they could graduate than freshmen students. This is understandable in that many seniors are aware of their graduation status, as opposed to freshmen who may have unrealistic expectations of their goals. However, a counterintuitive finding is that students who have a grade point average between a $2.0-2.5$ were less likely to feel that they could graduate in four years than students with a current GPA below 1.99. Additionally, students who are members of the Black Student Association were more likely than non-members to perceive that they can graduate in four years. Perhaps this may be a result of the support given to students by campusaffiliated groups; thus facilitating students' academic progression at school. An interesting finding is that students whose parents combined income is between 40,000 to 60,000 were less likely to feel they can graduate in four years than students whose parents' combined income is less than 40,000 .

\section{Combined Perceptions of Campus Climate}

In this section, the results of the combined perception model, defined as the sum of the social support, institutional support and self-efficacy indices are presented. When this combined model was run, six independent variables were found to be significant and their estimated coefficients and t-stats are presented in Table 21. 
Table 21

Independent Variables That Are Significant in all Three Areas of Campus Climate

\begin{tabular}{lccc}
\hline Independent variable & Reference category & Est. coefficient & T-Stat \\
\hline BSA & Nonmember & $4.98^{*}$ & 2.24 \\
Mother's highest level of education is a doctorate & Less than high school & $24.27^{*}$ & 2.04 \\
Gender & Female & $2.99^{*}$ & 2.05 \\
Live on Campus & Live off Campus & $3.47^{* *}$ & 2.71 \\
College GPA between 3.0 and 3.5 & Below 1.99 & $3.35^{*}$ & 2.56 \\
College GPA above 3.5 & Below 1.99 & $6.95^{*}$ & 2.77 \\
\hline
\end{tabular}

$* \mathrm{p}<.05 ; * * \mathrm{p}<.01$

The six significant variables for the overall index were very interesting and consistent with several of the findings from the individual indices mentioned previously. For example, all of the estimated coefficients were positive, ranging from 2.99 to 24.27 , and $\mathrm{R}^{2}$ explained $12 \%$ of the variation in the combined perceptions of campus climate for students.

With regards to students' overall perceptions of campus climate, several new findings emerged. Students whose mothers' highest level of education is a doctoral degree, were $25 \%$ more likely to have positive perceptions of campus climate. This is quite plausible considering that parents are role models that influence their child's education, provide support, and help facilitate the transition into school. Additionally, consistent with previous findings, students who have a current GPA above a 3.0, are members of the Black Student Association, or live on campus were more likely to have positive perceptions about campus supports. This is logical considering that students who live on campus are more exposed to, and aware of, social happenings on campus. In 
addition, males were $3 \%$ more likely to feel supported by the campus climate than females. This, again, supports earlier findings about females and how they were less likely than males to feel good about their current GPA.

\section{Respondents' Qualitative Information}

There was one opened-ended question included in the study. The responses to the open-ended question provided additional insights into students' perceptions of the school in general. Participants were asked to provide any additional comments pertaining to the social, institutional and academic support at the university that they considered important. Forty-two students provided feedback to the open-ended question; 35 of the responses were from females and seven were from males. Their responses are categorized in three different areas: (a) positive experience; (b) negative experience; and (c) recommendations on making it a better experience for other students. (Answers to the open-ended question can be found herein in Appendix C).

In general, the comments from the respondents concerning a positive experience ranged from enjoyment, easier adjustment as a member of a campus-affiliated program, organizational support, diversity and friendly campus. There were 12 responses categorized as positive. Students "love the school", feel that the university "has a beautiful and friendly campus", and feel that "most of the organizations on campus are supported and backed by the faculty and staff". The following quote is a more detailed example of one of the positive remarks. "The university provides more than enough social, institutional and academic supports for all students; this is a very diverse campus and if students on this campus need help, there is always someone to go to." 
There were also several negative remarks regarding the social climate at the university that may augment the findings. There were six responses categorized as negative. In general, students felt that there was a lack of social events, financial assistance for distance learning students and assistance with academics and after graduation options. Many of the students referred to the social life at the university as 'it needs help", the "social groups are not welcoming", "lacks a sense of community", "in desperate need of entertainment on the weekends", and "if you are not an on-campus student, you are not usually involved in the social gatherings". One student, in particular, commented about the professors, stating that "all of them really do not care or do not offer you the help you need", and "at least three of my professors have informed me to go to the tutoring labs for extra help". A more profound example of one of the negative comments is:

My academic advisor has changed every year I have been here for one reason or another. Many students feel lost as graduation approaches and are unsure of postgraduation options. For good students, graduate school is often chosen not because it is a passion for the students, but because they do not know what else to do.

Additionally, many of the comments scrutinized the social aspects of campus climate. The following quote illustrates the need for more social events. "The student body lacks a sense of community, I think if a petition were made, plenty of students would sign for a football team to help promote school unity and to give us more to do besides parties or clubs". 
There were several responses that were categorized as "recommendations on how to make the college experience better". In general, students offered ways in which the university could improve on social events and academic support. Twenty- four responses were classified as suggestions. The following quote is an example of a possible recommendation offered by a student.

Academics-some teachers don't care whether you fail or pass, more effort should be put into making sure students pass because I could put all the effort in the world in all of my classes and still fail, this is my major concern; also improving inner-student relations.

Another quote is from a student who recommends that “......an Alpha Kappa Alpha Sorority Inc. undergraduate and graduate chapter would make this a better school". The following quote is from a student who offers a suggestion for improving the academic and social supports of campus climate:

Academic supports- tutoring services for classes within certain majors such as Business/Finance do not offer flexible hours and are more first come first serve. Most people don't know about the academic support center where they can get assigned to meet with them 1 on 1 for certain disciplines. Unfortunately, they do not have an array of tutors for the disciplines offered. Social/sports clubs-the university should offer more sports clubs on an intramural level that is similar to those at the collegiate level....

In summary, the qualitative data clearly provides information that describes many positive aspects of campus in terms of the students' institutional, social and academic 
experiences, as well as articulates some of the negative aspects. The negative comments acknowledge the lack of social gatherings and events that would help facilitate social belonging and integration. In particular, some felt there was a lack of social groups and, in fact, felt that the university was in "desperate need" of social activities and entertainment. Students also felt the teachers were not caring and had been given little to no direction in terms of post-graduation options. However, the positive comments underscore the fact that the campus is quite diverse, friendly and offers organizations that support students. Moreover, students recommended that improving academic supports such as offering flexible hours for tutoring services, increasing support from professors, and offering more social clubs would make this a "better school".

\section{Summary of Significant Findings}

Overall the study revealed that the impact of gender on students' perceptions of campus climate was not significant, except for social support. There were, however, several factors that were significant in all three areas of campus climate.

\section{Significant Findings for Social Support}

As mentioned earlier, there was a statistically significant difference between male and females on their perceptions of social support. Overall, older students, who were male, single, lived on campus, had a job on campus, and were members of the Black Student Association, and sorority/fraternity were more likely to feel positive about social support at the school. In particular, males were more involved in intramural sports and the student union than females; and non-married students were more involved in extracurricular activities and social gatherings. As the study revealed, students who were not of senior status, and non-married were more likely to have their high school friends 
attend the university. This, perhaps, may contribute to an easier transition and increased social integration within the university. The findings from this study reveal that students who were exposed more to campus happenings through on-campus living and working on campus were more likely to feel positive about social supports as well as become involved with other activities such as the student union, extracurricular activities and social gatherings. As such it would behoove students to become members of the Black Student Association and or sorority/fraternity, since these behaviors were associated with increased involvement with other extracurricular activities and social gatherings.

Given that students' parents may affect their perceptions and behaviors about college, it is no surprise that parental factors, such as level of education and income were significant to students' perceptions of social support. In particular, students whose father has a college degree or higher were more likely to be involved with intramural sports, and students whose mother has a college degree were more likely to be involved with social gatherings at college. Additionally, a student whose parents combined income was 81,000-100,000 were less likely to have majority African American peers in high school than students whose parents combined income is below 40,000. A student whose mother's highest level of education was an associate degree was more likely to have high school friends attend the university. With a critical mass of students' high school peers at the school, this may contribute to an increase in students' social integration.

Significant Findings for Institutional Support

In terms of institutional support, there were very few significant findings that supported positive perceptions of institutional support. However, it was found that, overall, students whose father had less than a college education felt more institutional 
support. The support of the financial aid office was the only significant independent variable for institutional support. In particular, students who felt more supported by the financial aid office were those students who received financial aid, and were younger, instate students.

Significant Findings for Self Efficacy

With regards to students' self-efficacy and feelings of success at college, students' grade point average was a significant determinant of self-efficacy. Students with a GPA of 3.0 or above perceived themselves as being more self-efficacious. In particular, students who were more likely to feel good about their current academic progress, were older students with a grade point average of 3.0 or greater. Students who felt good about their capabilities of graduating from the school in four years were students who were married, affiliated with the Black Student Association, and whose parents' combined income was below 40,000 .

In addition, the qualitative data from the study provided further insights into social and institutional supports. In general, more students felt positive about the school environment than they did negatively; however, many suggestions were made to improve the school's social and academic supports. The negative comments concentrated on a lack of social life and academic help, while the positive comments were about the social organizations/activities and the diversity within the school. Many of the suggestions, however, focused on a need to endorse a football team, increase activities on the weekend and increase multicultural activities and training for staff. 


\section{Chapter Five \\ SUMMARY, CONCLUSIONS, DISCUSSION \\ AND RECOMMENDATIONS}

The final chapter presents a summary of the study's findings, discussion of the findings in the context of the existing literature, recommendations for future research, and policy recommendations for institutions of higher education.

To answer the research questions that guided this study, the aforementioned findings illustrate the extent of undergraduate African American students' perceptions of campus climate, as well as the extent to which these perceptions varied based on gender and/or other demographic factors. The study yielded some interesting findings in that there was little discrepancy in the gender differences of students' perceptions of campus climate, except for social support where there was a significant difference between male and female perceptions. Males, in particular, felt more social support than females and were more involved with intramural sports and the student union. There were also several demographic factors that were found to be significant in how African American students perceive campus climate.

Research Question 1

The first research question states: What perceptions do African American undergraduate students have about the campus climate? There was little discrepancy in the perceptions of campus climate among males and females. Black males' perceptions were slightly higher in social and institutional supports than females, and yielded a higher overall mean score for both social and institutional supports, 2.28 vs. 2.07 ; and 2.86 , and 2.78, respectively. Males, on average, were more likely to feel socially supported, in fact 
the difference between the means for males and females was statistically significant at the $\mathrm{p}=.01$ level. Additionally, the highest total average of all perceptions of campus climate was that of self-efficacy, both males and females scored the same, 2.94. Females felt most positively with having peers of other races, seeking tutorial services offered at the school, and that an education was very important. Conversely, females felt least positive about their involvement with intramural sports, meeting with their college advisor to go over academic progress, and their current college G.P.A. Males felt most positive with having peers of other races, that the faculty is fair to all students regardless of their racial background, and that education is very important. Males disagreed most to having high school friends attend the university, having their college advisor available when they need them, and their current college G.P.A.

\section{Research Question 2}

The second research question states: To what extent are the perceptions a function of gender? The study demonstrated that gender played a small part in the extent to which undergraduate African American students perceive campus climate. Gender was statistically significant in the social support construct of campus climate. Overall, males were more likely to be social integrated in the university; and they were more likely to be involved with the student union and intramural sports. Gender was not found to be significant in institutional supports and self-efficacy.

Research Question 3

The third research question states: To what extent are the perceptions of campus climate a function of other factors? The demographic variables explained the most variation in the student responses in the social supports construct. This construct yielded 
the highest $\mathrm{R}^{2}$ of $25 \%$, where age, gender, job on campus, member of the Black Student Association and sorority/fraternity, marital status, and living on campus were found significant. Institutional supports explained the least, suggesting that the demographic variables were not effective predictors of this measure. However, the demographic factors for students' perceptions of self-efficacy, explained $16 \%$ of the variation in the dependent variable, where students' current college GPA was most significant. The combined perception model explained $12 \%$ of the variation between the independent and dependent variables. This model indicated that a student whose mother's highest level of education is a doctoral degree was highly significant in his or her overall perceptions of campus climate.

\section{Discussion/Contribution to Literature}

The findings of this study corroborate with existing literature as well as add further insights concerning factors that impact students' perceptions of campus climate. The results of the study suggest that gender did not have a significant impact on African American students' perceptions of institutional supports and self-efficacy, but did for social supports. Therefore, unless social integration within the university is a factor that contributes to a student's academic performance, gender may not be a plausible explanation to the disparity in graduation rates among African American students at this particular institution.

There is a dearth of literature regarding gender differences in perceptions of college campus, and I would suggest that researchers further investigate intra-racial relations with a focus on how gender defines students' academic and social life on campus. Studies should specifically examine how environmental factors influence the 
way in which Black males and females come to perceive the college experience and how these perceptions influence their performance in school.

This study confronted the aforementioned issue by specifically examining Black students' perceptions of three aspects of campus climate at a predominately White institution. The study measured what the literature suggests as factors related to campus climate as well as self-efficacy. Students' self-efficacy is an important variable that describes the way in which students perceive their abilities; and how these self-fulfilling beliefs impact perceptions of college life. While much of the literature is replete with studies on cognitive factors related to race and comparative studies of Black and White student achievement, this study contributes to the literature by revealing the impact of gender and other demographic factors on perceptions of the school environment, as well as how those perceptions influence students' performance at school.

The study underscores several demographic variables that contribute to the current body of research on African American students' perceptions of campus climate at a predominately White institution. In general, the study concluded that non-married students were more likely to participate in social gatherings and extracurricular activities, and males were more likely to be involved with the student union and intramural sports. This finding supports Tinto's (1988) research, who asserts that intramural athletics may serve to provide individuals with opportunities to establish repetitive contact with other members of the institution and lead to the possibility of integration. The study also found the importance of living on campus, and being a member of sorority/fraternity helps students to become more socially integrated at school. In fact, in this study, students' residence, in particular, living on- campus, was one of the most important and pervasive 
variables that affected students' social integration. This supports Christie and Dinham (1991) who suggest that living on campus provides students with more of an opportunity to gain information and participate in social events on campus, and they are more likely to meet and develop friendships with other students.

The study revealed that students whose high school friends also went to the university were younger, non-married students. There was a positive correlation between single students and overall social integration within the school. Perhaps if single students have more high school friends attend the university, this may minimize alienation and contribute to positive feelings of social support. This finding, perhaps, may contradict Tinto's (1988) assertion that in order for students to become integrated within the university they must disassociate themselves socially from past communities. Contrary to this view, Nora and Cabrera (1996) state that attachments to friends and past communities play a key role in the successful transition of minority student adjustment to college. The study also revealed another noteworthy demographic variable that was significant to social integration: parents' level of education. There was a linkage between parents' education and social support; students whose father or mother had at least a college education were more likely to participate in sports and social gatherings.

The study also took in consideration the perceptions of the support of the financial aid office. The literature suggests that "financial problems" negatively impact minority students attending predominately White institutions, and is often the primary consideration in making decisions to persist in school (Jones, 2001). The study found that in-state students and younger students were more supported by the financial aid office than international students. This finding is quite disturbing in that students who live 
internationally tend to have higher tuition and would most likely benefit from financial assistance. Also, older students in their third or fourth year are closer to graduation and would need the support for continued financial assistance. This supports Dubrock's (2000) finding that financial aid attributes to college persistence especially in the second and third years of college.

A positive student- faculty relationship was another significant factor in helping to explain why some students felt more institutional support than others. The study revealed that Black males felt more strongly that faculty was fair to all students regardless of their racial background than females, and were approachable outside of the classroom. This finding is interesting in that there exist an obvious discrepancy in perceptions expressed by females and males regarding their academic performance, especially considering that more males had lower GPAs than females in this study and graduate at lower rates. It is therefore surprising that the positive perceptions of studentfaculty relationships seen by Black males were not reflected in their academic performance. This finding obviously contradicts what the existing literature says about student-faculty relationships. According to Terenzini (1980) student-faculty relationships were more of a predictor to persist or withdraw from school; and, according to Lang (1992), positive student-faculty relationships encourage students to study more. The positive perceptions of student-faculty relationships seen by Black males had a profound influence on their social behavior. As mentioned earlier, Black males were more socially integrated in the school. This supports Astin's (1984) assertion that students' interaction with the faculty is most strongly related with students" "satisfaction", and is an important 
indicator of how well Black males perceive the campus climate as well as their overall satisfaction with the university.

Black females, on the other hand, felt strongest about seeking help from tutoring services offered at the school. This supports Rowser's (1997) assertion that almost three times as many females as males perceive a need for tutoring, $45 \%, 16 \%$ respectively. Also, Sherman et at. (1994) contend that student retention is addressed in tutorial programs, and is especially important for African American students who struggle to remain in school after the first year. In general, considering the academic performance of Black males compared to their female counterparts, this is a critical component of institutional support that needs to be more utilized by Black males.

Another noteworthy finding that enhances the existing research is that both males and females felt least positive regarding the availability of their college advisor. This has implications that influence students' persistence in school, especially since Gibbs (as cited in Lang \& Ford, 1992) contends that Black students' seek academic counseling more than any other type of help, and are "three times more likely than Whites" to use academic services offered by the institution. The academic counselors provide students with the necessary resources pertaining to career choice, study skills and personal progress to facilitate matriculation throughout school. The importance of academic counselors to students is similarly stated by Willie et al. (1991) who claim that academic counseling helps students to matriculate and receive their degrees.

Furthermore, the study supports what the literature states about students' selfefficacy beliefs. The study revealed that both males and females perceived themselves as having a strong sense of self-efficacy. Black males and females purport to have strong 
commitments to graduating from the university, value education, and feel they have control over their futures. The study showed that the most significant variables for selfefficacy were students' current grade point averages. In general, students whose current academic performance was above a 3.0 had stronger feelings of self-efficacy. This finding is important in helping students accomplish goals; if they feel positive about their capabilities, this, perhaps, can influence students' motivation and commitment to continue the effort to do well. Bandura (2000) contends that unless people believe that they can provide effects they have little incentive to continue. Similarly, Sedlacek (1987) maintains that students will not make the commitment necessary to achieve unless they perceive themselves accomplishing goals. Therefore, the fact that students' academic performance is significant in their perceptions of self-efficacy, it is important to continue to offer students opportunities for success, especially Black males. Counter to this reasoning is that Black males' perceptions of their academic performance is, on average, positive, yet close to $65 \%$ of Black males had grade point averages below a 3.0 .

An additional finding emphasizes the need to consider additional supports for non-married students in reaching their goals to graduate in four years. The study found that only students who were married and not of senior status felt they could graduate from college in four years. This has implications on single students and students who are in their fourth year of school. Rankin (2003) who purports that if African American students are to be prepared for the $21^{\text {st }}$ century they must see themselves as competent and able to graduate from institutions of higher education. Therefore, more supports for single students and seniors should be recognized. 


\section{Limitations}

In view of the findings, it is important to discuss the limitations to the study that may have biased the results or distorted the views on how Black males and females perceive the campus climate at a predominately White institution.

Since the sample size in this study consisted of a total of 87 males and 279 females all from only one institution, the results cannot be generalized to undergraduate African American students in all schools. Also, because of the small sample size of Black male respondents, and since the students were not randomly assigned but self-selected, the results may not be indicative of the majority of Black males' views or perceptions at this institution. For example, many of the respondents may already be socially integrated within the university and are interested in making changes to the college campus, thus more apt to respond to the questionnaire.

Another variable that may have distorted the outcome of the study was the institution at which the study elicited student responses. Since this is a four-year public institution, the perceptions of campus climate may be profoundly different if done at a community college, larger university or private school. Lastly, the questionnaire for the study asked students to rate their perceptions of campus climate; however, the survey instrument may have skewed the results of students' perceptions in terms of not measuring their true perceptions, but instead abstract beliefs. The perceptions may be an ideological view of the dominant society on what is "expected" of them as opposed to their true perceptions of their own reality.

In sum, in view of the data presented herein, it is apparent that the perceptions of school environment were considerably more positive for Black males than females; 
however, their current academic performance and graduation rates at the school were not congruent with their view of campus climate. Males' had fewer grade point averages above a 3.0 than females, yet had responded, on average, more affirmatively to their perceptions of environmental factors. Perhaps the reason for the discrepancy in males' perceptions of campus climate and academic performance is attributed to what Rosalind Mickelon coins, "attitude achievement paradox". Even though Black males express, on average, positive perceptions of campus climate, this may be an "abstract articulation belief', where Black males truly do not feel education will lead to a better life (concrete belief). Therefore there is a contradiction between abstract and concrete beliefs, thus resulting in a discrepancy between the attitude expressed and their academic outcomes (Mickelson, 1990). Another explanation to this paradox is that there could be an unidentified resilience that Black females exhibit in the midst of adversity that helps them succeed academically despite their beliefs of campus climate.

\section{Recommendations for Future Research}

This study underscores several demographic variables that impact African American students' perceptions of campus relations at a predominately White institution. Given the study limitations in its scope of students, and the data retrieved from a single institution, it is suggested that future studies examine the perceptions of intra-racial groups at private four-year institutions as well as community colleges. This would hopefully help support, validate and generalize the limited findings of this study. To help enrich and substantiate these findings, more investigations should be conducted on the perceptual differences of African American students at small liberal arts schools compared to large research universities. It is also important to expand methodological 
procedures to triangulate findings such as using observations, interviews and case studies to determine factors related to the three areas of campus climate. It is also important to test for differences in campus climate between White institutions and Historically Black Colleges (HBCU's). Future research should focus on intra-racial perceptions as it pertains to campus climate with an emphasis on social integration. It is hypothesized that HBCU's are traditionally more conducive and comforting for Black students; therefore conducting empirically rich research that identifies specific campus-related factors that contribute to the student's success is needed.

Given the historically low graduation rates for Black males and their typically below average academic performance at school, it seems quite evident that their favorable perceptions/attitudes about campus climate contradicts their academic and graduation performance. Given the salient discrepancy in how Black males perceive their university experience compared to academic performance, it is quite possible that the way in which students are asked to view their perceptions is an inadequate measurement of students' academic performance. As mentioned earlier, the perceptions/attitudes of Black males expressed may not be a true reflection of a student's true reality, and may be an abstract view. An abstract perception is the belief that "education is an embodiment of an ideological view of the dominant society, where education is deemed as an opportunity for success and upward mobility" (Mickelson, 1990, p.46). However, this perception/attitude about education rarely predicts achievement behavior because it has little effect on students' true reality. Concrete perceptions/ beliefs about education, however, "accurately depict the students' diverse reality, and the opportunities significant adults in their lives have had in respect to their education, thus providing the context to 
view campus climate and their education positively or negatively"(Mickelson, 1990, p.45). Therefore, it is recommended that further empirical studies address students' concrete behaviors as opposed to abstract beliefs; and in doing so, expand upon the qualitative component of the research to examine individual student perceptions of college in the context of their own realities.

\section{Policy Recommendations}

It is incumbent upon institutions of higher education to provide an equal and appropriate education for all of their students. In particular, colleges and universities are responsible for providing students with the necessary skill set, knowledge, and potential to be successful citizens ready for society's workforce. According to the Institute for Higher Education Policy (2003), the proportion of the total U.S. population comprised of minorities is expected to grow from $28 \%$ in the year 2000 to $36 \%$ in 2020 and $47 \%$ in 2050. By 2015, college enrollments are expected to increase by $5 \%$ for Whites, compared to $23 \%$ for African Americans. With the expected increase in minority students in institutions of higher education, it is imperative for policy makers to recognize and prepare for a shift in demographics. It is important to have a broader understanding of programs and policies that meet the needs of all students. It is equally important for schools to be cognizant of the social and academic needs of Black students, particularly males whose graduation rates are at ominous proportions compared to their Black female cohorts.

Administrators at colleges and institutions of higher education could begin by identifying the problems faced by Black males, comparing their academic and social behaviors/perceptions to Black females and how these factors attribute to persistence; 
then, mandate programs and initiatives to improve their success rate. For example, given the findings of this study, it is recommended that faculty members and advisors play more of an integral part in students' academic life by closely monitoring the academic progress of African American students, especially focusing on male achievement. For example, college faculty and advisors could monitor students on a regular basis through a 3-step process. This process might consist of a data base program that alerts the student's advisor of one or more underachieving grades in the course of a semester. Then the faculty, advisor, and student would work in collaboration with one another to identify a plan of action that incorporates long and short-term goals with a commitment from the student until the goal is achieved. The third step would then be to contact the tutoring and academic counseling department to schedule academic support for the student. In light of the data from this study, it is especially important for advisors to encourage Black males to seek tutoring and academic assistance on a regular basis, and to monitor student progress, and to encourage and support students to graduate in four years.

It is also necessary that efforts be made to create a mentoring program for incoming students. This will allow students to develop relationships with other students as well as interact with on-campus groups in an effort to expose students to social activities on campus. In light of the findings of this study, this would especially be beneficial for Black females, who need to perceive the social and academic climate as inclusive and affirming; and will hopefully promote and encourage the participation in activities offered at the school. It is also important for schools to develop a summer long seminar and/or workshop for African American students whose high school academic record is marginal. At the summer workshop students will have the opportunity to meet 
with their college advisors, learn about college activities and a variety of social and academic supports. The seminar could offer a summer long reading, math and study skills program to help students learn effective work habits to help with their academic workload once they enter school. In addition, it is important for institutions of higher education to collaborate with $\mathrm{K}-12$ public schools to establish early intervention programs to strengthen academic preparation and promote educational planning.

Also, given the findings of this study, the university should provide literature to incoming students with information on how to access tutoring and academic services, and promoting on-campus living, extracurricular activities, social events, and activities on campus, since this leads to more positive perceptions of social support. In addition, a Brother-to-Brother, or Sister-to-Sister program could be implemented where in-coming African American students could be assigned a mentor, possibly a student who is a member of a sorority or fraternity. This will expose students to Greek life and other associations on campus. The mentor could be assigned to the student for the first year of school; preference would be given to students who had low academic performance in high school, are out-of-state students, and have submitted a letter of interest. This will help with attrition within the first two years of college, and expose students more easily to academic and social supports.

Moreover, given the findings of the perceptions of institutional supports at this university, it is recommended that administrators within the financial aid office offer workshops within the first two weeks of the beginning of the semester as well as a one week long session in the summer. At the information session students will become familiar with the process of obtaining financial assistance, grants, and scholarships, as 
well as the type of financial aid available. They will also have the opportunity to ask questions and seek advice. This would especially benefit international students who, according to the findings in this study, feel less supported.

\section{Conclusion}

While there were limitations of this study, there were several interesting findings that contribute to the literature concerning African American students' perceptions of campus climate at a predominately White institution. The data elicited from the survey presented several insights into how African American male and females perceive their college environment at one particular university. This study revealed how important it is to look at intra-racial gender differences by quantifying their perceptions in an effort to determine the extent that gender and other demographic factors affect students' academic persistence in school. 


\section{References}

Allen, W.R. (1992). The color of success: African-American college student outcomes at predominantly White and historically Black public colleges and universities. Harvard Educational Review, 62(1), 26-43.

Alliance for Equity in Higher Education. (2003). Policy priorities for the Higher Education Act Reauthorization. Retrieved March 4, 2005, from the Alliance for Equity in Higher Education Web site. http://www.msialliance.org/csc/cscdocs/Febraruy2003.htm

Armstrong, W.B. \& Carty, H.M. (2001). Analyzing the relationship between perceptions of the research university campus climate and student outcomes: An exploratory analysis. (Tech. Rep. No. 143). California Association for Institutional Research.

Astin, A.W. (1984). Student Involvement: A developmental theory for higher education. Journal of College Student Personnel, 25, 297-308.

Astin, A. W. (1975). Preventing students from dropping out. San Francisco: Jossey-Bass.

Bandura, A. (2000). Cultivating self-efficacy for personal and organizational effectiveness. Handbook of Principals of Organizational Behavior, 120136. Oxford, UK: Blackwell.

Bandura, A., Barbaranelli, C., Vittorio, C., \& Pastorelli, C. (1996). Multifaceted impact of self-efficacy beliefs on academic functioning. Child Development, 67, 1206-1222.

Berry, M., \& Asamen, K. (1989). Black students: psycho-social issues and academic achievement. Newbury Park, Sage Publishing.

BET.com (2003). Black women outpacing Black men. Retrieved July 11, 2003, from http://www.bet.com/articles/0,c3gb6140-6892,00.html

Bureau of Justice Statistics.(2004). Criminal offenders statistics. Retrieved April 8, 2005 from http:/www.ojp.usdoj.gov/bjs/crimoff.htm

Carter, D.F. (2001). A dream deferred: Examining the degree aspirations of African American and White college students. New York: RoutlegdgeFalmer.

Clayton, M. (2001). Gender gap is far from academic for colleges. The Christian Science Monitor. Retrieved March 19, 2003 from http://www.csmweb2.emcweb.com 
Choy, S.P., (2002). The findings from 10 years of longitudinal research on students. The George Washington University, U.S. Department of Education, retrieved February 14, 2003, from http://www.eriche.org/digesgts/2002-2.html

Christie, N.G., \& Dinham, S.M. (1991). Institutional and external influences on social integration in the freshman year. The Journal of Higher Education, 62(4), 412-436.

Cohen, L., Lawrence, M. \& Morrison, K. (2002). Research methods in education. $5^{\text {th }}$ Edition. New York: RoutledgeFalmer Publishing.

Coley, R. (2001). Gender differences similar across racial/ethnic groups. Educational Testing Service online. Retrieved March 19, 2003 fromhttp:/www.ets.org/news/01022601.html

Cose, E. (2003). From schools to jobs: Black women are rising much faster than Black men: What it means for work, family and race relations. Newsweek, 48-50.

Cross, T. (1999). Special Report. College degree awards: The ominous gender gap in African American higher education. Journal of Blacks in Higher Education, 23, 6-9.

Cross, T. (1998). Why the large and growing gender gap in African American higher education? Journal of Blacks in Higher Education, 0(19), 34-35.

Cross, T. (1997). The marriage dilemma of college-educated Black women. Journal of Blacks in Higher Education, 0(17), 52-53.

Cross, T. (1994). Higher education gains by Black women are across the board. Journal of Blacks in Higher Education, 0(6), p. 49.

Cross, T. (1994). Women dominate the honor rolls at Black colleges. Journal of Blacks in Higher Education, 0(6), 46-47.

Davis, J.E. (2003). Early schooling and academic achievement of African American males. Urban Education, 38(5), 515-533.

Davis, J.E. (1998). Campus climate, gender, and achievement of AfricanAmerican college students. Retrieved February 12, 2003, from http://www.rcgd.isr.umich.edu/prba/perspectives/spring 1998/jdavis.pdf

Dilulio, J.J. (1994). The question of Black crime. Public Interest, 117, 1-16. 
Dubrock, C. P. (2000). Financial aid and college persistent: A five-year longitudinal study of 1993 and 1994 beginning freshmen students. Paper presented at the Annual Forum of the Association of Institutional Research, Cincinnati, $\mathrm{OH}$.

Education Week. (2005). Table: math and reading differences. 24 (16), 5.

Ferguson, R. (2005). Closing the gap. National Education Association, $23(4), 22-31$.

Flannery, M., \& Jehlen, A. (2005). Closing the gap. National Education Association, 23(4), 22-31.

Fleming, J. (1984). Blacks in college. San Francisco: Jossey-Bass.

Gewertz, C. (2004). Black males lagging behind in graduation rates.

Education Week, 24 (14), 14.

Gibbs, J.T. (1988). Young, Black and male in America: An endangered species. Massachusetts: Auburn House Publishing Company.

Gonzales, L.M. (2002). Making connections: Addressing the pitfalls of White faculty/Black male student communication. National Council of Teacher of English Online. Retrieved March 23, 2003 from http:

Gordon, J.U. (2002). The Black male in White America. New York: Nova Science Publishers, Inc.

Green, J.M., Peschiera, C., Shuleva, J.E. \& Stricken, E. The victims: Targets of racism. Retrieved February 14, 2003, from http: www.units. muchio.edu/psybersite/racism/victims.shtml

Harvey, W. (2003). The data speak: No rest for the weary. Making it on broken promises: Leading African American male scholars confront the culture of higher education. Sterling: Stylus Publishing.

Hawkins, D.B. (1996). Gender gap. Black Issues in Higher Education, 13(10), 20.

Hong, S.H. (2002). More Black women than men in college, journal finds.

Uwire.com. Retrieved March 19, 2003 from

http://www.uwire.com/content/topnews 120502003.html.

Hood, D.W. (1992). Academic and non-cognitive factors affecting the retention of Black men at a predominately White university. The Journal of Negro Education, 61(1), 12-23. 
Irvine, J. (1990). Black students and school failure: Policies, practices and prescriptions. New York: Greenwood Publishing

Johnson, D. (2002). The alarming decline of the academic performance of African American men. African Radio online. Retrieved February 23, 2003, from http://www.africana.com/DailyArticles/index_20000430.htm

Jones, L. (2002). Making it on broken promises. Leading African American male scholars confronting the culture of higher education: Sterling Virginia: Stylus Publishing, LLC.

Jones, L. (2001). Retaining African Americans in higher education: Challenging paradigms for retaining students, faculty and administrators. Stylus Publishing: Sterling, Virginia

Kim, S.H., \& Sedlacek, W.E. (2003). Gender differences among incoming African American freshmen on academic and social expectations. Counseling center. Retrieved July 13, 2003, from http://www.inform.umd.edu/EdRes/Topic/Diversity/General/Reading/Sedlacek/fr eshmen.html

Kuykendal, C. (1992). From rage to hope: Strategies for reclaiming Black and Hispanic students. National Educational Service: Bloomington, Indiana.

Lang, M. (1992). Barriers to Blacks' educational achievement in higher education. A statistical and conceptual review. 22(4), 510-522.

Lang, M. \& Ford, C.A. (1992). Strategies for retaining minority students in higher education. Charles Thomas Publisher: Springfield, Illinois.

LaVeist, Whigham-Desir, M. (2002). Top 50 colleges for African Americans. Black Enterprise 29 (6), 71-80, Retrieved March 11, 2003 from http://wwwf.countryday.net/college/top 50 .htm

Leach, E.J. (2001). Brother-to-brother: Enhancing the intellectual and personal growth of African American males. World Wide Web Edition, 14(3). Retrieved February 10, 2004 from www.league.org/publication/abstrats/learning/lelabs0111.html

Mayo, M.W. \& Christenfeld, N. (1999). Gender, race and performance expectations of college students. Journal of Multicultural Counseling, 27(2), 93-105. 
McCombs, B.L. (1991). Overview: Where have we been and where are we going in understanding human motivation? Journal of Experimental Education, $60(1), 5-14$.

Mickelson, R.A. (1990). The attitude achievement paradox among Black adolescents. Sociology of Education, 63(11), 44-61.

Mitchell, S.L., \& Dell, D.M. (1992). The relationship between Black students' racial identity attitude and participation in campus organizations. Journal of College Student Development, 33, 39-43.

National Urban League. (1998). Retrieved July, 2004, from http:/www.nul.org/news/2004/jobless rel2.html,

Newcomb, T.M., \& Wilson E.K, (1966). College peer groups: Chicago, IL: Aldine

Nettles, M.\& Perna, L., (1997). The African American Education Data Book.

Volume I: Higher and Adult Education. Frederick D. Patterson Research Institute.

Nineteenth Annual Status Report on Minorities in Higher Education, (2001).

Retrieved February 25, 2003 from

http://www.acenet.edu/program/omhe/status-report/e-summary.cfm

Noguera, P. (2003). The trouble with Black boys: The role and influence of environmental and cultural factors on the academic performance of African American males. Urban Education, 38 (4), 431-459.

Nora, A., \& Cabrera, A.F. (1996). The role of perceptions of prejudice and discrimination on the adjustment of minority students to college. The Journal of Higher Education, 67(2), 119-148.

Ogbu, J. (2003). Black students in an affluent suburb: A study of academic disengagement. Mahwah, NJ: Lawrence Erllbaum.

Pascarella, E.T., \& Terenzini, P.T. (1991). How college affects students. San Francisco: Jossey-Bass.

Pascarella, E.T., Terenzini, P.T., \& Wolfe, L.M. (1986). Orientation to college and freshmen year persistence/withdrawal. The Journal of Higher Education, 57(2), 155-175.

Pascarella, E.T., \& Terenzini, P.T. (1980). Predicting freshman persistence and voluntary dropout decision from a theoretical model. Journal of Higher Education, 15, 60-75. 
Polite, V.C., \& Davis, J.E. (1999). African American males in school and society. practices and policies for effective education. New York, NY: Teachers College Press.

Porter, M., \& Bronzaft, A. (1995). Do the future plans of educated Black women include Black mates? Journal of Negro Education, 64(2), 162.

Rankin, C. (2003). Equity and excellence: Is there room for African American Ph.D's? Making it on broken promises: Leading African American male scholars confront the culture of higher education. Sterling: Stylus Publishing Company.

Rowser, J.F. (1997). Do African American students' perceptions of their needs have implications for retention? Journal of Black Studies 27(5), 718-726.

Sedlacek, W.E. (1987). Black students on White campuses: Twenty years of research. Journal of College Student Personnel, 28(6), 484-495.

Scott, M. (2002) Black Women bemoan shortage of Black men. Savannah Morning News on the Web, Retrieved, March 19, 2003 from http://www. search.yahoo.com $/$ search?p=black+bales+and+black + females + in + college $\& b=21$ $\&$ hc $=0$ \&hs $+1 \&$ xargs $=0$

Sherman, T.M., Giles, M.B. \& Williams-Green, J. (1994). Assessment and retention of Black students in higher education. Journal of Negro Education, 63(2), 164-178.

Slater, R.B. (1994). The growing gender gap in Black higher education. The Journal of Blacks in Higher Education, 3, 52-59.

Statistical Abstract of the United States (2002). $122^{\text {nd }}$ Edition. Bernan Press.

Steele, C. (1992). Race and the schooling of Black americans. The Atlantic Online. Retrieved April 7, 2003 from http://www.the atlantic.com/politics/race/steele.htm

Stikes, S.C. (1984). Black students in higher education. Southern Illinois: University Press.

Tinto, V. (1988). Stages of student departure: Reflections on the longitudinal character of student leaving. The Journal of Blacks in Higher Education, 59 (4), 438-455. 
Tinto, V. (1987). Leaving College: Rethinking the causes and cures of student attrition. The University of Chicago press: Chicago, Illinois.

Tracey T.J., \& Sedlacek, W.E. (1985). The relationship of non-cognitive variables to academic success: A longitudinal comparison by race. Journal of College Student Personnel, 405-410.

Washington, V., \& Newman. J. (1991). Setting our own agenda: Exploring the meaning of gender disparities among Blacks in higher education. Journal of Negro Education, 60 (1), 19-35.

Willie, C.V., Garibaldi, A.M. \& Reed, W.L. (1991). The education of AfricanAmericans. William Monroe Institute, University of Massachusetts, Boston, Massachusetts. 
Appendix A

Letter of Introduction to Undergraduates

August 2004

Dear Undergraduate:

My name is Tiffany Carpenter and I am conducting research on students' perceptions of general campus climate at Old Dominion University. I am interested in learning about African American students' perceptions concerning institutional, social and academic supports at ODU. Your feedback on this survey is extremely important as it provides an assessment of the campus experience as perceived by undergraduate students. After the data are analyzed, the results of the study will be included in my final doctoral dissertation.

To assist me in creating a study that will impact the future of students' college experience, please complete the following on-line survey by clicking on the link below. If you self identify as African American, please answer every question as sincerely and as reflectively as possible. Please be assured that all of your responses will remain anonymous and confidential. If you have any questions please feel free to contact either my advisor, Dr. Fred Galloway at galloway@sandiego.edu or me at (240) 483-9295 or via email at nicolecarpenter@hotmail.com

Thank you for taking the time to contribute to this important issue in higher education. If you would like to receive a summary of the findings, please indicate your interest via email.

Sincerely,

Tiffany Carpenter University of San Diego

Ed.D Candidate 
Please make sure you take this survey only once. You must be 18 years or older to take this survey.

\section{Appendix B}

\section{Questionnaire}

Part I- Social Supports

Check the box that represents your perception of the following statements based on your experience at this university.

\begin{tabular}{|l|l|l|l|l|l|}
\hline \multicolumn{1}{|c|}{ Statement } & $\begin{array}{c}\text { Strongly } \\
\text { Agree }\end{array}$ & Agree & Neutral & Disagree & $\begin{array}{l}\text { Strongly } \\
\text { Disagree }\end{array}$ \\
\hline $\begin{array}{l}\text { 1. The majority of the students at my high } \\
\text { school were African American. }\end{array}$ & & & & & \\
\hline $\begin{array}{l}\text { 2. The majority of my high school friends attend } \\
\text { college. }\end{array}$ & & & & & \\
\hline $\begin{array}{l}\text { 3. My peer group (people you spend time with) } \\
\text { at this university is African American. }\end{array}$ & & & & & \\
\hline $\begin{array}{l}\text { 4. Most of my high school friends attend this } \\
\text { university. }\end{array}$ & & & & & \\
\hline $\begin{array}{l}\text { 5. I feel comfortable with peers who are African } \\
\text { American. }\end{array}$ & & & & & \\
\hline $\begin{array}{l}\text { 6. I am involved in intramural sports at this } \\
\text { university. }\end{array}$ & & & & & \\
\hline 7.I am involved with the student union. & & & & & \\
\hline $\begin{array}{l}\text { 8. I am involved with other extracurricular } \\
\text { activities not mentioned above. }\end{array}$ & & & & & \\
\hline $\begin{array}{l}\text { 9. I often participate in social gatherings at this } \\
\text { university. }\end{array}$ & & & & & \\
\hline $\begin{array}{l}\text { 10. It has been easy for me to make friends with } \\
\text { others at this university. }\end{array}$ & & & & & \\
\hline $\begin{array}{l}\text { 11. Most of the students here have values the } \\
\text { same as my own. }\end{array}$ & & & & & \\
\hline 12. I am satisfied with my social life here. & & & & \\
\hline
\end{tabular}

\section{Part II- Institutional Supports}

Check the box that represents your perception of the following statements based on your experience at this university.

\begin{tabular}{|c|l|l|l|l|l|}
\hline Statement & $\begin{array}{c}\text { Strongly } \\
\text { Agree }\end{array}$ & Agree & Neutral & Disagree & $\begin{array}{c}\text { Strongly } \\
\text { Disagree }\end{array}$ \\
\hline $\begin{array}{c}\text { 13. My college advisor is available when I } \\
\text { need him/her. }\end{array}$ & & & & & \\
\hline $\begin{array}{c}\text { 14. My college advisor has met with me to } \\
\text { go over my academic progress. }\end{array}$ & & & & & \\
$\begin{array}{c}\text { 15. This university has provided me with } \\
\text { counseling resources if I need them. }\end{array}$ & & & & & \\
\hline $\begin{array}{c}\text { 16. This university has provided me with } \\
\text { mentoring resources if I need them. }\end{array}$ & & & & & \\
\hline $\begin{array}{c}\text { 17. I feel supported by the academic services } \\
\text { offered here. }\end{array}$ & & & & & \\
\hline $\begin{array}{c}\text { 18. The financial aid office has been } \\
\text { supportive in meeting my financial needs. }\end{array}$ & & & & & \\
\hline $\begin{array}{c}\text { 19. The faculty is approachable outside of the } \\
\text { classroom. }\end{array}$ & & & & \\
\hline
\end{tabular}




\begin{tabular}{|c|c|c|c|c|c|}
\hline Statement & $\begin{array}{l}\text { Strongly } \\
\text { Agree }\end{array}$ & Agree & Neutral & Disagree & $\begin{array}{l}\text { Strongly } \\
\text { Disagree }\end{array}$ \\
\hline $\begin{array}{l}20 . \text { The faculty is fair to all students } \\
\text { regardless of their racial background. }\end{array}$ & & & & & \\
\hline $\begin{array}{l}\text { 21. I would seek help from tutoring services } \\
\text { offered at the school if I needed it. }\end{array}$ & & & & & \\
\hline $\begin{array}{l}\text { 22. The academic advisors and counselors at } \\
\text { this institution are concerned with my academic } \\
\text { performance. }\end{array}$ & & & & & \\
\hline $\begin{array}{l}\text { 23. My professors listen to my comments or } \\
\text { questions. }\end{array}$ & & & & & \\
\hline 24. My professors encourage me to do my best. & & & & & \\
\hline
\end{tabular}

Part III- Academic Goals/Commitment

Check the box that represents your perception of the following statements based on your experience at this university.

\begin{tabular}{|c|c|c|c|c|c|}
\hline Statement & $\begin{array}{l}\text { Strongly } \\
\text { Agree }\end{array}$ & Agree & Neutral & Disagree & $\begin{array}{l}\text { Strongly } \\
\text { Disagree }\end{array}$ \\
\hline 25. I feel that I can be successful here. & & & & & \\
\hline 26. I feel good about my current GPA & & & & & \\
\hline $\begin{array}{l}\text { 27. I feel confident in taking on challenges } \\
\text { in my courses. }\end{array}$ & & & & & \\
\hline $\begin{array}{l}28 \text {. I can graduate from college in four } \\
\text { years. }\end{array}$ & & & & & \\
\hline $\begin{array}{l}\text { 29. I can meet all academic goals given by } \\
\text { my professors. }\end{array}$ & & & & & \\
\hline 30. I don't compare myself to others. & & & & & \\
\hline $\begin{array}{l}\text { 31. I am committed to graduating from } \\
\text { this university. }\end{array}$ & & & & & \\
\hline 32. I have plans to pursue graduate school. & & & & & \\
\hline 33. I am motivated to do well in school. & & & & & \\
\hline 34. An education is very important to me. & & & & & \\
\hline 35. I have control over my future. & & & & & \\
\hline $\begin{array}{l}36 . \text { I look to others to help me before I } \\
\text { begin a challenging task. }\end{array}$ & & & . & & \\
\hline
\end{tabular}

\section{Part IV. Demographic}

Please read each item carefully and fill in the appropriate response to the questions.

\section{What is your Gender?} Male Female

39. What is your residency status? In-state Out-of-State International student

41. What is your class designation? Freshman Senior Sophomore Junior

38. What is your age?

40. What is your current housing? arrangement? Off campus On campus

42. What is your current cumulative GPA?

Below 1.99

2.0-2.49

2.5-2.99

$3.0-3.5$

above 3.5 
43. Are you a member of a collegiate sports team?

$$
\text { Yes }
$$
No

45. How many siblings do you have?

47. What is your mother's formal level of education?

Less than high school

High school graduate

Associates degree

College graduate

Master's degree

Doctoral degree

48. What is the combined level of income of your parents?

Below 40,000

$40,000-60,000$

$61,000-80,000$

$81,000-100,000$

above 100,000

50. Do you work on-campus? Yes No

51. Are you a member of a Sorority or Fraternity? Yes No

52. What is your HIGH SCHOOL GPA?

Below 1.99

2.0-2.49

$2.5-2.99$

3.0-3.5

above 3.5

53. Are you currently using some type of financial aid?

Yes No

54. Full-time ___ Part-time

55. Are you a member of the Black Student Association?

56. Of the colleges to attend was this school your first choice? Yes No

57. Are there any additional comments that you would like to make about social, institutional and academic supports here at the university that you consider important?
44. What is your marital status? Single Married Divorced

46. What is your father's formal level of education High school graduate Associate degree College graduate Master's degree Doctoral degree

49. How many hours per week do you work?
Less than high school 


\begin{abstract}
Appendix C
African American Students' Perceptions of Campus Climate at a Predominately White Southeastern University Survey

November 2004

Answers to Open-ended Question
\end{abstract}

\title{
Question:
}

Are there any additional comments that you would like to make about social, institutional and/or academic supports here at the university that you consider important?

Responses are categorized according to central themes.

\section{Positive College Experience}

Survey \#

4

9

44

57

104

115

\section{Comment}

Keep up the good work X school

Let's go MONARCH! WOO!

I think it was easier for me than others to adjust because

I was a member of the Monarch Dance Team for two

years. I was obligated to participate in social activities.

I am currently an active member of many different

on campus clubs, which helps a lot

I love this School

This university is a very diverse campus and all of the programs here reflect that. In addition, the staff reflects the level of diversity as well. This university was not my $1^{\text {st }}$ choice, but after I got in to my $1^{\text {st }}$ choice and weighed the pros and cons this school came out on top!

This school has a beautiful and friendly campus

Female

Most of the organizations on campus are supported and backed by the faculty and staff
Female

Gender

Female

Female

Male 

cultures. I frown upon racism; frown upon the confederate flag. I am mixed and extremely interested about the results of this survey on the issue of students feeling uncomfortable around students of different races or cultures

This school provides more than enough social, institutional and academic support for all students. This is a very diverse campus and if students on this campus need help, there is always someone to go to

I enjoy attending classes here. I hope to persuade my 16-year old son to choose this school when he graduates from high school

Ebony Impact Gospel Choir has helped me so much socially and spiritually

I love it here

I feel that this school in general is very diverse

\section{Negative College Experiences}

This is a great school academically, but socially, it really needs help. I can understand that college is what you make, but I thought my experience would have been a little better then it currently is now.

Some social groups are not welcoming at all

This is my first semester here and I am trying to learn these teachers. I am trying to meet new friends but it has not been easy. My time is so limited that my social life stinks. Hopefully in the spring semester I will be a lot better. I guess it is because I am older and most of these students here are younger. The students here may probably feel threatened by my looks. I guess I need a mentor or some one to motivate me to have me to regain my confidence. I transferred from Tidewater Community College at Virginia Common Wealth University. I had a lot of friends in both places. Maybe because this is my first semester here. I guess a couple of semesters here, I may meet new friends.
Female

Female

Female

Female

Female

Male

Female

Female

Female 
here) and when I was there the instructors were more approachable when it came to asking for extra help. Here at least 3 of my instructors have informed me to go to the tutoring labs for extra help. I am also an IDS major and it is hard for me to find assistance with my proposal

My academic advisor has changed every year I have been Male here for one reason or another. Many students feel lost as graduation approaches and are unsure of post-graduation options. For good students, graduate school is often chosen not because it is a passion of the students, but because they don't know what else to do for an on-campus social life

Female

\section{Suggestions on how to make the college experience better}

The school needs to bring back the Webb Jam or something, because there is nothing to do on the weekends (seriously)

I feel that this university has a special treatment to the Greek life; and also they need help with funding and housing costs. It's a shame that people can't come to school because housing is so expense. There are people here that don't need financial aid and its discouraging me that I almost didn't come to the "school of my dreams" because I didn't have the money

Academic Support-Tutoring services for classes within certain majors such a Business/Finance do no offer flexible hours and are more on first come first serve services. Most people don't know about the academic support center here where they can get assigned to a tutor to meet with 1 on 1 for certain disciplines. Unfortunately, they don't have an array of tutors for the disciplines offered. Social/Sports clubs-ODU should offer more sports clubs on an intramural level that is similar to those at the collegiate level. I played intramural soccer last semester when I had fewer classes, but I would love to play tennis/women's softball at the intramural level $\mathrm{b} / \mathrm{c}$ I don't think I qualify at the collegiate level.

There needs to be more activities for the weekend

Need more courses geared towards Black students
Female

Male

Female

Male

Female 
Academics-some teachers don't care whether you

Female fail or pass, more effort should be put into making sure students pass because I could put all the effort in the world into a class and still fail, this is my major concern, also improving inter-student relations make advisors and professors go through some formal training on multicultural students, so they can get rid of some of the stereotypes many of these professor have about students from different races and cultures is not at all helpful. I found that of the entire faculty. I have had the most unpleasant interaction with her a petition were made, plenty of students would sign for a football team to help promote school unity and to give us more to do besides going to parties or clubs I checked that I do not belong to a sorority, however I am planning on pledging. I would like to be involved in more activities. The school should have another Kaufman mall outing with various events and activities but I feel one way that it could be boosted $100 \%$ is by adding a football team 

not usually involved in the social gatherings and/or other academic support programs. You may hear about them but when you don't have time to just sit on campus and you have to go to work or take care of a home, it is hard to be so totally involved in school, period of individual organization, I would like to see more of a stress on multicultural activities not just one cultural explosion a year. We should be more focused on unity than diversity, but still good to acknowledge that fact, also when it comes to teachers, all of them really don't care or don't offer you the help you need. They want you to have questions, but never really take the responses into consideration, because I never see a change

This school is a very diverse school; however, I still believe that it is segregated when it comes to

Male social events, especially during activity period. It seems as if the African Americans use one part of the web and the Caucasians us the other part

Football team and more social activities, and more academic majors

Female

Not all professors here teach you. They expect for you teach yourself, and asks questions if you need to. This is

Female an area that could be improved on 